\title{
Primary cutaneous lymphomas - diagnostic and therapeutic guidelines of the Polish Dermatological Society
}

\author{
Chłoniaki pierwotnie skórne - rekomendacje diagnostyczno-terapeutyczne Polskiego \\ Towarzystwa Dermatologicznego
}

Małgorzata Sokołowska-Wojdyło', Joanna Maj², Ewa Robak ${ }^{3}$, Waldemar Placek ${ }^{4}$, Anna Wojas-Pelc ${ }^{5}$, Alina Jankowska-Konsur², Karolina Olek-Hrab ${ }^{6}$, Robert Gniadecki ${ }^{7,8}$, Lidia Rudnicka ${ }^{9}$

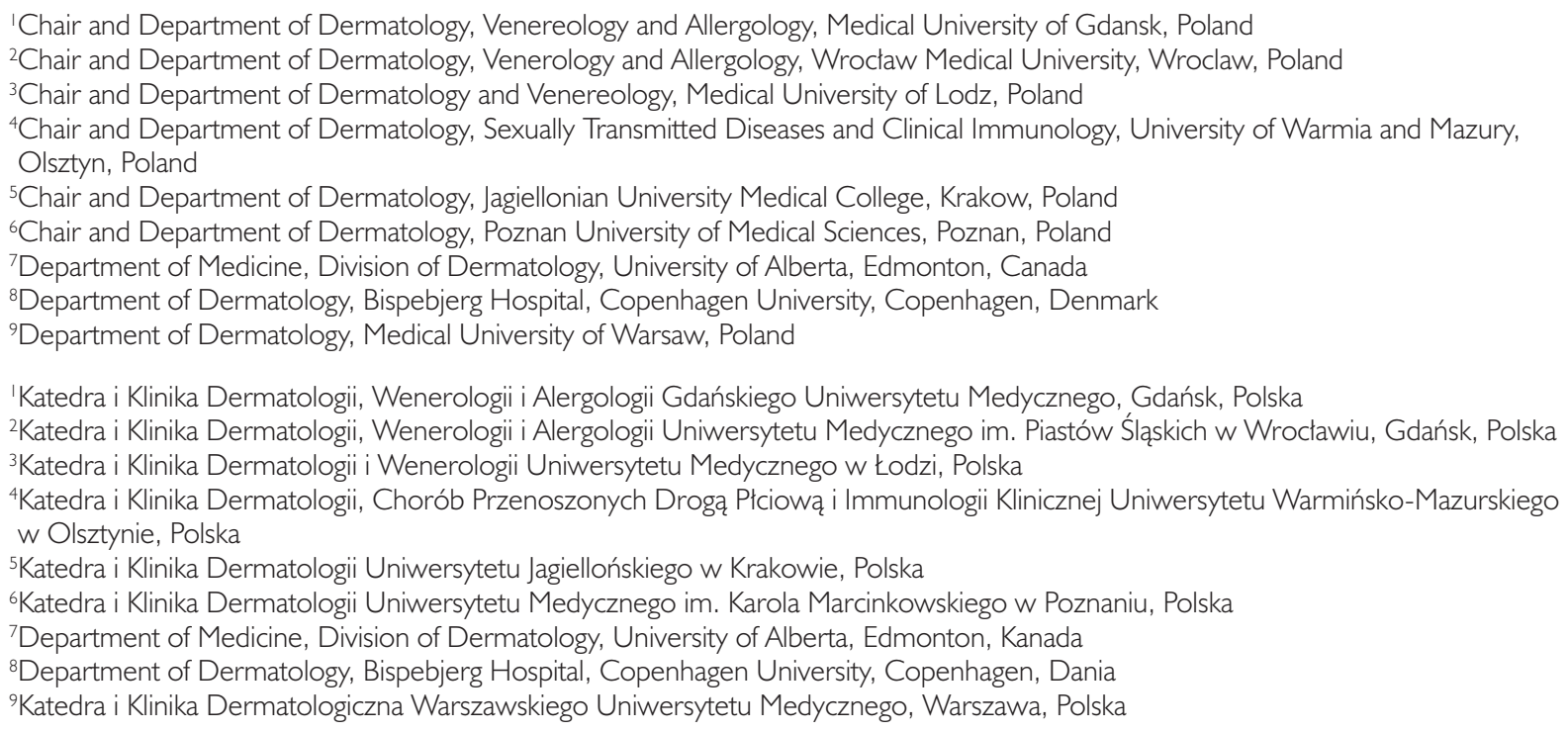

\section{CORRESPONDING AUTHOR/ ADRES DO KORESPONDENCJI: dr hab. n. med. Małgorzata Sokołowska-Wojdyło Katedra i Klinika Dermatologii, Wenerologii i Alergologii Gdański Uniwersytet Medyczny ul. Dębinki 7 \\ 80-210 Gdańsk, Polska tel.: +48 602618195 e-mail: mwojd@gumed.edu.pl}

\begin{abstract}
Primary cutaneous lymphomas are a group of rare lymphoproliferative diseases with incompletely understood pathogenesis. They comprise cutaneous T-cell lymphomas, cutaneous B-cell lymphomas and T/NKcell lymphomas. The aim of the guidelines is to provide physicians with a tool to facilitate the diagnostic and therapeutic process in patients with this group of diseases. The updated recommendations are consistent with the guidelines for haematologists and oncologists, which will enable the unification of diagnostics and therapy conducted by physicians of all specialties. However, it is important to note that therapeutic decisions must be made individually on the basis of the general condition of the patient, history of internal diseases and medicines used, with careful consideration of the potential efficacy and safety profile of the proposed treatment, which may differ from patient to patient.
\end{abstract}

\section{STRESZCZENIE}

Chłoniaki pierwotnie skórne to grupa rzadkich rozrostów limfoproliferacyjnych o nie do końca poznanej patogenezie. Do grupy tej należą rozrosty T-komórkowe, B-komórkowe oraz z komórek T/NK. Celem niniejszych rekomendacji jest ułatwienie lekarzom procesu diagnostycznego i terapii pacjentów z tą grupą chorób. Uaktualnione zalecenia są zbieżne $\mathrm{z}$ rekomendacjami dla hematologów i onkologów, co 
pozwoli na ujednolicenie diagnostyki i terapii prowadzonych przez lekarzy wszystkich specjalności. Należy jednak pamiętać, że decyzje terapeutyczne lekarz musi podejmować indywidualnie, w zależności od stanu ogólnego pacjenta, obciążeń internistycznych, przyjmowanych leków, kierując się potencjalną skutecznością i profilem bezpieczeństwa, które mogą być różne u różnych pacjentów.

Key words: guidelines, lymphomatoid papulosis, diagnostics, treatment, mycosis fungoides.

Słowa kluczowe: rekomendacje, lymphomatoid papulosis, diagnostyka, leczenie, ziarniniak grzybiasty.

\section{INTRODUCTION}

Primary cutaneous lymphomas (PCLs) are a heterogeneous group of non-Hodgkin's lymphomas of the lymphatic system differing in clinical and histopathological features, immunophenotype and prognosis. Characteristically, PCLs only involve the skin at the time of diagnosis. About $65 \%$ of PCLs originate from mature $\mathrm{T}$ lymphocytes in the skin (cutaneous T-cell lymphoma - CTCL), 25\% - from mature B cells (cutaneous B-cell lymphoma-CBCL), and the remaining proportion - from NK (natural killer) cells. The estimated annual incidence of CTCL and CBLC is $0.7-0.8$ and 0.3 per 100,000 population, respectively (Tab. 1). Factors predisposing to the development of lymphomas of this type are as yet unknown. The pathogenesis of the disease is believed to involve genetic, immunological and environmental factors. Attention has been given to the link between mucosa-associated lymphoid tissue (MALT) lymphoma and Helicobacter pylori infection, the inducing effect of human T-cell lymphotropic virus 1 (HTLV-1) on the development of adult T-cell leukaemia/lymphoma - or the relationship between Epstein-Barr virus (EBV) infection and NK/T-cell lymphoma of the nasal type [1-3]. The role of certain drugs, such as hydrochlorothiazide, in the progression of mycosis fungoides (MF) has also been considered, however it is possible that the drug induces a pseudolymphoma state. Furthermore, the incidence of the disease has been found to be higher in some professions, for example carpenters [3, 4]. CTCL originate from the so-called skin-homing CD4 + CD45RO+ memory T cells. Cancerous (effector memory) T lymphocytes in the skin in MF express the cutaneous lymphocyte antigen (CLA) as well as CCR4, CCR6 and CCR10 (CC-chemokine receptors 4, 6 and 10). In Sézary syndrome (SS) cancerous lymphocytes express CCR7 and L-selectin (central effec-

\section{WPROWADZENIE}

Chłoniaki pierwotnie skórne (primary cutaneous lymphomas - PCL) to heterogenna grupa nowotworów nieziarniczych układu chłonnego, różniących się obrazem klinicznym, histopatologicznym, immunofenotypem oraz rokowaniem. Cechą charakterystyczną PCL jest zajęcie procesem chorobowym tylko skóry w chwili ustalania rozpoznania. Około 65\% PCL wywodzi się z dojrzałych limfocytów T skóry (cutaneous T-cell lymphoma - CTCL), 25\% z dojrzałych komórek B (cutaneous B-cell lymphoma - CBCL), a pozostałe z komórek NK (natural killer). Częstość zachorowań na CTCL szacuje się na 0,7-0,8 na 100000 osób rocznie, a CBCL - 0,3 na 100000 osób rocznie (tab. 1). Nie są znane czynniki promujące rozwój tych chłoniaków. W patogenezie choroby podkreśla się rolę czynników genetycznych, immunologicznych i środowiskowych. Podkreślano związek rozwoju chłoniaka typu MALT (mucosa-associated lymphoid tissue) z infekcją Helicobacter pylori, indukujący wpływ wirusa HTLV-1 (human T-cell lymphotropic virus 1) na rozwój chłoniaka T-komórkowego dorosłych białaczka/ chłoniak (adult T-cell leukemia/lymphoma) czy infekcję wirusem Epsteina-Barr (EBV) z chłoniakiem NK/ T-komórkowym typu nosowego [1-3]. Rozważana jest rola leków, m.in. hydrochlorotiazydu, w progresji ziarniniaka grzybiastego (mycosis fungoides - MF), choć możliwe, że lek ten prowadzi do rozwoju stanu pseudochłoniakowego. Ponadto stwierdzono, że częściej chorują osoby wykonujące niektóre zawody, np. cieśle [3, 4]. Nowotwory CTCL wywodzą się z tzw. skin-homing limfocytów T pamięci CD4+CD45RO+. Nowotworowe limfocyty T (efektorowe pamięci) w MF w skórze wykazują m.in. ekspresję antygenu CLA (cutaneous lymphocyte antigen), a także CCR4 oraz CCR6 i CCR10 (CC-chemokine receptors 4, 6 i 10). W zespole Sézary'ego (Sézary syndrome - SS) nowotworowe limfocyty wykazują ekspresję CCR7 
Table I. Classification and frequency of mature T-, NK- and B-cell primary cutaneous lymphomas according to the World Health Organization $(\mathrm{WHO})[2,12]$

Tabela I. Klasyfikacja i częstość występowania pienwotnych nowotworów skóry z dojrzałych komórek T i NK oraz komórek B wg Światowej Organizacji Zdrowia (World Health Organization - WHO) $[2,12]$

\section{Subtype/Podtyp $\quad$ Frequency/ 5-year survival rate/}

Częstość (\%) 5-letnie przeżycie (\%)

$\mathrm{CTCL}$ - indolent clinical behaviour/CTCL o powolnym przebiegu

\begin{tabular}{|c|c|c|}
\hline mycosis fungoides (MF)/ziarniniak grzybiasty (MF): & 44 & 88 \\
\hline folliculotropic MF/MF odmiana folikulotropowa & 4 & 80 \\
\hline pagetoid reticulosis/siatkowica pagetoidalna & $<1$ & 100 \\
\hline granulomatous slack skin/MF typu skóry obwisłej i ziarniniakowej & $<1$ & 100 \\
\hline lymphomatoid papulosis (LyP)/lymphomatoid papulosis (LyP) & 12 & 100 \\
\hline $\begin{array}{l}\text { primary cutaneous anaplastic large cell lymphoma (C-ALCL)/pierwotny skórny chłoniak } \\
\text { z dużych komórek anaplastyczny (C-ALCL) }\end{array}$ & 8 & 95 \\
\hline $\begin{array}{l}\text { subcutaneous panniculitis-like T-cell lymphoma (SPTCL)/chłoniak z komórek T tkanki } \\
\text { podskórnej typu zapalenia tkanki podskórnej (SPTCL) }\end{array}$ & I & 82 \\
\hline $\begin{array}{l}\text { primary cutaneous small/medium pleomorphic CD4+ T-cell lymphoma (CSMTLC)/ } \\
\text { pierwotny skórny chłoniak z małych/średnich komórek T CD4+ (CSMTCL) }\end{array}$ & 2 & 72 \\
\hline
\end{tabular}

$\mathrm{CTCL}$ - aggressive clinical behaviour/CTCL o agresywnym przebiegu

\begin{tabular}{lcc}
\hline Sézary syndrome (SS)/zespół Sézary'ego (SS) & 3 & 24 \\
\hline $\begin{array}{l}\text { primary cutaneous peripheral T-cell lymphoma, unspecified/pierwotny skórny chłoniak } \\
\text { z komórek T, podtyp nieokreślony }\end{array}$ & 2 & 16 \\
\hline $\begin{array}{l}\text { primary cutaneous aggressive epidermotropic CD8 T-cell lymphoma (AECTCL)/ } \\
\text { pierwotny skórny agresywny epidermotropowy chłoniak z komórek CD8+ (AECTCL) }\end{array}$ & $<1$ & 18 \\
\hline $\begin{array}{l}\text { primary cutaneous } \gamma / \delta \text { T-cell lymphoma (PCGD-TCL)/pierwotny skórny chłoniak } \\
\text { z komórek T } \gamma / \delta(P C G D-T C L)\end{array}$ & $<1$ & - \\
\hline $\begin{array}{l}\text { primary cutaneous (extranodal) NK/T-cell lymphoma, nasal-type/ pozawęzłowy chłoniak } \\
\text { z komórek NK/T typu nosowego }\end{array}$ & $<1$ \\
\hline $\begin{array}{l}\text { CBCL } \\
\text { primary cutaneous follicle centre lymphoma (PCFCL)/pierwotny skórny chłoniak } \\
\text { z ośrodków rozmnazania (PCFCL) }\end{array}$ & 95 \\
\hline $\begin{array}{l}\text { primary cutaneous marginal zone B-cell lymphoma (PCMZL)/ pozawęzłowy chłoniak } \\
\text { strefy brzeżnej (PCMZL) }\end{array}$ & 7 \\
\hline $\begin{array}{l}\text { primary cutaneous diffuse large B-cell lymphoma, leg type, (PCLBCL)/pierwotny skórny } \\
\text { chłoniak rozlany z dużych komórek B typu kończynowego (PCLBCL, leg type) }\end{array}$ & 4 \\
\hline
\end{tabular}

tor memory T cells) and may be detected not only in the skin but also in the lymph nodes and peripheral blood, which confirms their migratory potential. In CD30+ lymphomas the growth of a neoplastic clone is crucially dependent on the interactions between CD30 and its ligand, and between the transforming growth factor $\beta$ (TGF- $\beta$ ) and its receptor, resulting in spontaneous remissions and relapses. Also, the development of some B-cell lymphomas is related to the proliferation of mature B cells in the course of inflammatory process (link to Borrelia burgdorferi infection) [5-13]. i L-selektyny (centralne efektorowe komórki T pamięci) i są wykrywane nie tylko w skórze, lecz także w węzłach chłonnych i krwi obwodowej, co potwierdza ich potencjał migracyjny. W chłoniakach CD30+ istotna dla regulacji wzrostu klonu nowotworowego jest interakcja CD30 i ligandu, a także transformującego czynnika wzrostu $\beta$ (transforming growth factor $\beta$ - TGF- $\beta$ ) i receptora, prowadząca do samoistnych remisji i nawrotów. Z kolei rozwój niektórych chłoniaków typu $\mathrm{B}$ wiąże się $\mathrm{z}$ rozrostem dojrzałych komórek B na podłożu procesu zapalnego (związek $\mathrm{z}$ infekcją Borrelia burgdorferi) [5-13]. 


\section{DIAGNOSTICS, STAGING AND TREATMENT RESPONSE CRITERIA}

The diagnosis of PCL should be based on a combination of clinical features, histopathological examination of the skin or, less commonly, the lymph node, and immunophenotypic analysis of infiltrating lymphocytes. Skin biopsy specimens should not be taken from seborrhoeic areas, abdominal skin or necrotic lesions. Before performing a biopsy the skin should not be treated with any steroid agents or phototherapy for a minimum of 2 weeks (as far as possible), as these therapeutic modalities may significantly alter the histopathological characteristics of the skin. Histopathological examinations should preferably be repeated (even several times) because of the complex nature of the infiltration. In cases of lymphadenopathy the whole lymph node should be removed for biopsy in order to assess the degree of distortion in nodal architecture. The lymph nodes selected for biopsy should preferably be hard, not freely movable, with a minimum diameter of $1.5 \mathrm{~cm}$. The extent of skin lesions is assessed with the Wallace rule of nines and/or the palm rule. In therapeutic programmes and clinical trials the severity of the disease is assessed according to the modified Severity Weighted Assessment Tool (mSWAT). The Tumour-Nodes-Metastasis-Blood (TNMB) classification should be used for precise clinical staging (Tab. 2 and 3 applicable to MF and SS) [5-8, 11-13].

Imaging studies (radiography, computed tomography) are useful in cases with extensive skin lesions and/or lymphadenopathy, and/or suspected internal organ involvement (not in MF stages IA-IIA). Complete blood count (CBC) of peripheral blood should be performed in all patients. In cases of erythroderma or extensive skin lesions an additional examination should be immunophenotyping of peripheral blood (diagnostic criteria: loss of CD26 on more than $30 \%$ of CD4+ cells and/or loss of CD7 on more than $40 \%$ of the cells or the minimum $\mathrm{T} 4 / \mathrm{T} 8$ ratio of $10: 1)$. A peripheral blood smear and cytological examination are required in search of Sézary cells. The concentration of lactate dehydrogenase (LDH) in the blood may be high in cases of internal organ involvement secondary to lymphoma. Monoclonal rearrangement of T-cell receptors (TCRs) found in a single biopsy does not presuppose the cancerous nature of lesion. For the proliferation to be recognized as cancerous, both in the evaluation of the skin, lymph nodes and peripheral blood, the clone must be identical in multiple locations (similarly to the evaluation of several skin specimens collected from various lesions in the same patient). Response to treatment and monitoring of the course of the disease require the application of the modified Severity Weighted Assessment Tool (mSWAT) (Tab. 4 and 5) [5-8, 14, 15].

\section{DIAGNOSTYKA, OCENA STOPNIA ZAAWANSOWANIA I KRYTERIA ODPOWIEDZI NA LECZENIE}

Podstawą ustalenia rozpoznania jest obraz kliniczny, badanie histopatologiczne skóry, rzadziej węzła chłonnego oraz określenie immunofenotypu naciekających limfocytów. Biopsji skóry nie należy pobierać z okolic łojotokowych, skóry brzucha i z ognisk martwicy. Skóra przed wykonaniem biopsji nie powinna być przez minimum 2 tygodnie (jeśli to możliwe) leczona preparatami steroidowymi, a także metodą fototerapii, które mogą poważnie zmienić obraz histopatologiczny. Wskazane jest powtarzanie badań histopatologicznych (nawet wielokrotnie) ze względu na złożony charakter nacieku. W przypadku limfadenopatii zaleca się pobranie całego węzła chłonnego w celu oceny stopnia zaburzenia jego architektury. Węzły chłonne wskazane do biopsji są twarde, nieprzesuwalne względem podłoża, o średnicy $1,5 \mathrm{~cm}$ lub większej. Ocenę rozległości zmian skórnych przeprowadza się zgodnie z regułą dziewiątek Wallace'a i/lub regułą dłoni. W programach terapeutycznych i badaniach klinicznych w ocenie stopnia nasilenia choroby zastosowanie znajduje skala mSWAT. W celu precyzyjnego ustalenia zaawansowania klinicznego należy zastosować klasyfikację Tumor-Nodes-Metastasis-Blood (TNMB) (tab. 2 i 3 w odniesieniu do MF i SS) [5-8, 11-13].

Badania obrazowe (rentgenowskie - RTG, tomografii komputerowej - TK) są pomocne, gdy zmiany skórne są rozległe i/lub występuje limfadenopatia, i/lub podejrzewa się zajęcie narządów wewnętrznych (nie w MF IA-IIA). U wszystkich chorych należy wykonać morfologię krwi obwodowej, a w przypadku erytrodermii lub rozległych zmian skórnych - immunofenotypowanie krwi obwodowej (kryteria rozpoznania: utrata CD26 na ponad 30\% komórek, CD4+ i/lub CD7 na ponad 40\% komórek lub T4/T8 minimum $10: 1)$. Konieczne jest wykonanie rozmazu krwi obwodowej i badanie cytologiczne w poszukiwaniu komórek Sézary'ego. Stężenie dehydrogenazy mleczanowej (lactate dehydrogenase - LDH) we krwi bywa duże, gdy w przebiegu chłoniaka zajęte są narządy wewnętrzne. Stwierdzenie monoklonalności rearanżacji receptorów limfocytów T (T-cell receptor - TCR) w pojedynczej biopsji nie przesądza o nowotworowej naturze zmiany. W przypadku oceny zarówno skóry, węzłów chłonnych, jak i krwi obwodowej klon musi być identyczny w kilku lokalizacjach, aby świadczył o nowotworowym charakterze rozrostu (podobnie jak przy ocenie kilku wycinków skóry $\mathrm{z}$ różnych zmian u tego samego pacjenta). Monitorowanie odpowiedzi na leczenie oraz przebiegu choroby wymaga zastosowania modified Severity Weighted Assessment Tool (mSWAT) (tab. 4 i 5) [5-8, 14, 15]. 
Table 2. Classification of cutaneous, nodular, organ and peripheral blood involvement in mycosis fungoides and the Sézary syndrome according to the International Society for Cutaneous Lymphomas and the European Organisation of Research and Treatment of Cancer (2007), and the Tumour-Nodes-Metastasis-Blood (TNMB) classification (20 I0) [5-8, I I-13]

Tabela 2. Klasyfikacja zmian skórnych, węzłowych, narzqdowych i zmian we krwi obwodowej w przebiegu ziarniniaka grzybiastego i zespołu Sézary'ego wg International Society for Cutaneous Lymphoma oraz European Organisation for Research and Treatment of Cancer z 2007 r. i klasyfikacji Tumor-Nodes-Metastasis-Blood z 2010 r. [5-8, II-13]

\begin{tabular}{|c|c|}
\hline \multicolumn{2}{|r|}{ Skin/Zmiany skórne } \\
\hline TI: & $\begin{array}{l}\text { limited patches*, papules and/or plaques** covering }<10 \% \text { of the skin surface/tylko zmiany rumieniowe*, grudki } \\
\text { i/lub zmiany naciekowe*** pokrywające }<10 \% \text { powierzchni skóry }\end{array}$ \\
\hline $\mathrm{Tla}$ & patches only ( $<10 \%$ of the skin surface)/tylko zmiany rumieniowe ( $<10 \%$ powierzchni skóry) \\
\hline TIb & plaques and patches ( $<10 \%$ of the skin surface)/zmiany rumieniowe i naciekowe (< $10 \%$ powierzchni skóry) \\
\hline T2: & $\begin{array}{l}\text { patches, papules or plaques covering } \geq 10 \% \text { of the skin surface/zmiany rumieniowe, grudki i zmiany naciekowe } \\
\text { pokrywające } \geq 10 \% \text { powierzchni skóry }\end{array}$ \\
\hline $\mathrm{T} 2 \mathrm{a}$ & patches only ( $\geq 10 \%$ of the skin surface)/tylko zmiany rumieniowe ( $\geq 10 \%$ powierzchni skóry) \\
\hline $\mathrm{T} 2 \mathrm{~b}$ & plaques and patches ( $\geq 10 \%$ of the skin surface)/zmiany rumieniowe i naciekowe ( $\geq 10 \%$ powierzchni skóry) \\
\hline T3 & one or more tumours**** $(\geq \mid \mathrm{cm}$ diameter)/co najmniej jeden guz**** (średnica $\geq 1 \mathrm{~cm}$ ) \\
\hline T4 & $\begin{array}{l}\text { confluence of erythema covering } \geq 80 \% \text { of body surface } \\
\text { powierzchni skóry }\end{array}$ \\
\hline
\end{tabular}

*For skin, patch indicates any size skin lesion without any significant elevation or induration. Presence/absence of hypo- or hyperpigmentation, scale, crusting and/or poikiloderma should be noted. ***For skin, plaque indicates any size skin lesion that is elevated or indurated. Presence or absence of the same features as for patches should be noted. Additional features such as folliculotropism, large-cell transformation (> 25\% large cells), and presence or absence of CD3 expresion should be noted. ***Tumour indicates a solid lesion at least I cm in diameter with evidence of depth and/or vertical growth. Note the total number of lesions, total volume of lesions, largest size lesion, and the region of body involved, and the above-mentioned histologic features (CD30 expression, large-cell transformation)./*Każda zmiana skórna (niezależnie od wielkości), która nie jest w sposób istotny uniesiona i twarda. Należy odnotować nadmierna pigmentację, niedostateczna pigmentację, złuszczanie, strupy, poikilodermię. ***Każda zmiana skórna (niezależnie od wielkości), która jest uniesiona lub twarda. Należy odnotować dodatkowe cechy, podobnie jak w przypadku zmiany rumieniowej, oraz uwzględnić ewentualny folikulotropizm, transformację wielkokomórkowq (> 25\% dużych komórek), ekspresję lub brak ekspresji CD30. ****Zmiana lita o średnicy $\geq 1 \mathrm{~cm}$ wrastajqca w głab skóry illub ponad jej poziom. Należy odnotować liczbę zmian, ich całkowitq̨ objętość, wielkość największej zmiany oraz zajętq̨ okolicę ciała, a także wymienione wyżej cechy histologiczne (ekspresja CD30, transformacja wielkokomórkowa).

\section{Node/Zmiany węzłowe}

N0 no clinically abnormal* peripheral lymph nodes (i.e. cervical, supraclavicular, epitrochlear, axillary, and inguinal); biopsy not required/w badaniu klinicznym nie stwierdza się nieprawidłowych* obwodowych węzłów chłonnych (tj. szyjnych, nadobojczykowych, nadkłykciowych, pachowych i pachwinowych); biopsja węzła chłonnego nie jest wymagana

\begin{tabular}{|c|c|}
\hline $\mathrm{NI}:$ & $\begin{array}{l}\text { clinically abnormal* peripheral lymph nodes; histopathology Dutch grade I or NCI LN0-2/w badaniu klinicznym } \\
\text { stwierdza się nieprawidłowe* obwodowe węzły chłonne; histologicznie w klasyfikacji holenderskiej stopień I. } \\
\text { (Dutch I) lub w klasyfikacji NCl stopień LNO-2 }\end{array}$ \\
\hline $\mathrm{Nla}$ & 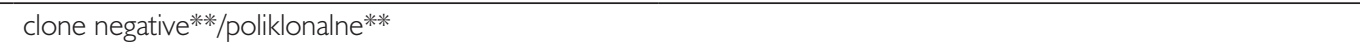 \\
\hline$\overline{N I b}$ & clone positive**/monoklonalne** \\
\hline N2: & $\begin{array}{l}\text { clinically abnormal* peripheral lymph nodes; histopathology Dutch grade } 2 \text { or NCI LN3/w badaniu klinicznym } \\
\text { stwierdza się nieprawidłowe* obwodowe węzly chłonne; histologicznie w klasyfikacji holenderskiej stopień } 2 . \\
\text { (Dutch 2) lub w klasyfikacji NCl stopień LN3 }\end{array}$ \\
\hline $\bar{N} 2 a$ & clone negative***/ poliklonalne** \\
\hline $\mathrm{N} 2 \mathrm{~b}$ & clone positive**/monoklonalne** \\
\hline N3 & $\begin{array}{l}\text { clinically abnormal* peripheral lymph nodes; histopathology Dutch grades 3-4 or NCI LN4; clone positive } \\
\text { or negative**/w badaniu klinicznym stwierdza się nieprawidłowe* obwodowe węzły chłonne; histologicznie } \\
\text { w klasyfikacji holenderskiej stopień 3.-4. (Dutch 3-4) lub w klasyfikacji NCl stopień LN4; poli- lub monoklonalne*** }\end{array}$ \\
\hline $\mathrm{Nx}$ & $\begin{array}{l}\text { clinically abnormal* peripheral lymph nodes; no histologic confirmation/w badaniu klinicznym stwierdza się } \\
\text { nieprawidłowe* obwodowe węzły chłonne; bez potwierdzenia histologicznego }\end{array}$ \\
\hline
\end{tabular}

*For node, abnormal peripheral lymph node(s) indicates any palpable peripheral node that on physical examination is firm, irregular, clustered, fixed, or $\geq 1.5 \mathrm{~cm}$ in diameter. Central nodes, which are not generally amenable to pathologic assessment, are not currently considered in the nodal classification. ***A T-cell clone is defined by polymerase chain reaction (PCR) or Southern blot analysis of the T-cell receptor (TCR) gene./ *Nieprawidłowy obwodowy węzeł chłonny to wyczuwalny, twardy, nieregularny obwodowy węzeł chłonny, także w pakietach, albo nieruchomy względem podłoża lub skóry, albo o średnicy $\geq 1,5 \mathrm{~cm}$. Obecność patologicznych centralnych węzłów chłonnych, niedostępnych rutynowej diagnostyce patologicznej nie znajduje odzwierciedlenia w opisanej klasyfikacji. ***Klonalność komórek T określa się metodq łańcuchowej reakcji polimerazy (PCR) lub Southern Blot, oceniajq̨c klonalność rearanżacji genów TCR. 
Table 2. Continued

Tabela 2. Ciqg dalszy

\begin{tabular}{|c|c|c|}
\hline \multicolumn{3}{|c|}{ Histopathological staging of lymph nodes/Stopnie zaawansowania histopatologicznego węzłów chłonnych } \\
\hline $\begin{array}{l}\text { ISCL/EORTC } \\
\text { classification/ } \\
\text { Klasyfikacja } \\
\text { ISCL/EORTC }\end{array}$ & Dutch system/System holenderski & $\mathrm{NCl}-\mathrm{VA}$ \\
\hline $\mathrm{NI}$ & $\begin{array}{l}\text { grade I: dermatopathic lymphadenopathy }(\mathrm{DL}) / \\
\text { stopień I.: odczynowe zapalenie węztów chłonnych } \\
\text { (DL, dermatopathic lymphadenopathy) }\end{array}$ & $\begin{array}{l}\text { LN0: no atypical lymphocytes/ LNO: brak atypowych } \\
\text { limfocytów } \\
\text { LN I: occasional and isolated atypical lymphocytes (not } \\
\text { arranged in clusters)/LNI: przypadkowe i pojedyncze } \\
\text { atypowe limfocyty (nietworzące grup) } \\
\text { LN2: many atypical lymphocytes or in 3-6 cell clusters/ } \\
\text { LN2: liczne atypowe limfocyty lub grupy liczące po 3-6 } \\
\text { komórek }\end{array}$ \\
\hline N2 & 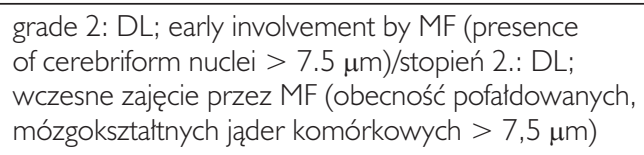 & $\begin{array}{l}\text { LN3: aggregates of atypical lymphocytes; nodal architecture } \\
\text { preserved/LN3: skupiska atypowych limfocytów; } \\
\text { zachowana architektura węzła chłonnego }\end{array}$ \\
\hline N3 & $\begin{array}{l}\text { grade 3: partial effacement of LN architecture; many } \\
\text { atypical cerebriform mononuclear cells (CMCs)/ } \\
\text { stopień 3.: częściowe zatarcie architektury węzła } \\
\text { chłonnego; obecność licznych jednojądrowych } \\
\text { komórek o pofałdowanych jądrach (CMCs) } \\
\text { grade 4: complete effacement/stopień 4.: całkowite } \\
\text { zatarcie architektury węzła chłonnego }\end{array}$ & $\begin{array}{l}\text { LN4: partial/complete effacement of nodal architecture } \\
\text { by atypical lymphocytes or frankly neoplastic cells/ } \\
\text { LN4: czéściowe lub całkowite zatarcie architektury } \\
\text { węzła chłonnego przez limfocyty atypowe lub komórki } \\
\text { nowotworowe }\end{array}$ \\
\hline
\end{tabular}

\begin{tabular}{ll} 
Visceral/Zmiany w narządach wewnętrznych \\
M0 no visceral organ involvement/bez zajęcia narządów wewnętrznych \\
\hline MI & $\begin{array}{l}\text { visceral involvement (must have histopathological confirmation* and the organ involved should be specified)/zajęcie } \\
\text { narządów wewnętrznych (niezbędne potwierdzenie histopatologiczne* oraz wskazanie zajętego narządu) }\end{array}$ \\
\hline
\end{tabular}

*For viscera, spleen and liver may be diagnosed by imaging criteria./*W przypadku wątroby i śledziony można stosować kryteria obrazowe.

Peripheral blood/Zmiany we krwi obwodowej

B0: $\quad$ absence of significant blood involvement or $\leq 5 \%$ of peripheral blood lymphocytes are atypical (Sézary) cells/bez cech zajęcia krwi obwodowej lub $\leq 5 \%$ limfocytów krwi obwodowej stanowią komórki atypowe (Sézary'ego)

\begin{tabular}{|c|c|}
\hline $\mathrm{BOa}$ & clone negative*/poliklonalne* \\
\hline$\overline{B O b}$ & clone positive*/monoklonalne* \\
\hline $\mathrm{Bl}:$ & $\begin{array}{l}>5 \% \text { of peripheral blood lymphocytes are atypical (Sézary) cells but does not meet the criteria of B2/>5\% } \\
\text { limfocytów krwi obwodowej stanowią komórki atypowe (Sézary'ego), ale ich liczba jest mniejsza niż próg } \\
\text { określony w definicji stopnia B2 }\end{array}$ \\
\hline $\mathrm{Bla}$ & clone negative*/poliklonalne* \\
\hline$\overline{B I b}$ & clone positive*/monoklonalne* \\
\hline
\end{tabular}

*A T-cell clone is defined by PCR or Southern blot analysis of the T-cell receptor (TCR) gene. ***For peripheral blood, Sézary cells are defined as lymphocytes with hyper-convoluted cerebriform nuclei. If the number of Sézary cells cannot be assessed, then one of the following ISCL criteria should be used: I) expanded CD3 + or CD4 + cells with CD4/CD8 ratio of $\geq 10$; and 2) expanded CD4 + cells with abnormal immunophenotype, including loss of CD7 or CD26)./ *Klonalność komórek T określa się metoda PCR lub Southern Blot, oceniajac klonalność rearanżacji genów TCR. ***W przypadku krwi obwodowej komórki Sézary'ego definiuje się na podstawie morfologii jądra komórkowego (silnie pofałdowane, mózgokształtne). Jeżeli nie można ocenić liczebności komórek Sézary’ego, należy wykorzystać zmodyfikowane kryteria opracowane przez ISCL: 1) rozrost komórek CD3 + lub CD4+ przy stosunku CD4/CD8 wynoszq̨cym > 10 lub 2) rozrost komórek CD4+ o nieprawidłowym immunofenotypie (tj. z utratą CD7 i CD26).

MF - mycosis fungoides, NCI - National Cancer Institute, NCI-VA - National Cancer Institute - Veterans Affairs, PCR - polymerase chain reaction, TCR - T-cell receptor.

MF - ziarniniak grzybiasty, NCl - National Cancer Institute, NCI-VA - National Cancer Institute - Veterans Affairs, PCR - reakcja łańcuchowa polimerazy, TCR - receptor T-komórkowy. 
Table 3. Clinical stages and prognosis in mycosis fungoides and the Sézary syndrome according to the International Society for Cutaneous Lymphoma (ISCL) and European Organisation of Research and Treatment of Cancer (EORTC) [5-8, I2]

Tabela 3. Stopnie zaawansowania klinicznego i rokowanie w ziarniniaku grzybiastym i zespole Sézary'ego wg International Society for Cutaneous Lymphoma oraz European Organisation for Research and Treatment of Cancer [5-8, 12]

\begin{tabular}{|c|c|c|c|}
\hline $\begin{array}{l}\text { Stage/ } \\
\text { Stadium }\end{array}$ & TNM & Clinical presentation/Objawy kliniczne & $\begin{array}{l}\text { 5-year } \\
\text { survival/ } \\
\text { Przeżycie } \\
\text { 5-letnie (\%) }\end{array}$ \\
\hline IA & TI NO MO BO- I & $\begin{array}{l}\text { patches and plaques }<10 \% \text { body surface area/rumienie i nacieki }<10 \% \text { powierzchni } \\
\text { ciała }\end{array}$ & 98 \\
\hline IB & T2 NO MO BO-I & $\begin{array}{l}\text { patches and plaques }>10 \% \text { body surface area/rumienie i nacieki }>10 \% \text { powierzchni } \\
\text { ciała }\end{array}$ & 89 \\
\hline$\| A$ & $\begin{array}{l}\mathrm{TI}-2 \mathrm{NI}-2 \mathrm{MO} \\
\mathrm{BO}-\mathrm{I}\end{array}$ & $\begin{array}{l}\text { skin lesions as in stage I, lymphadenopathy without histopathologic evidence of } \\
\text { lymphoma/skóra jak w fazie I, limfadenopatia bez cech histopatologicznych chłoniaka }\end{array}$ & 89 \\
\hline IIB & T3 NO-2 MO BO-I & $\begin{array}{l}\text { tumours, lymphadenopathy without histopathologic evidence of lymphoma/guzy, } \\
\text { limfadenopatia bez cech histopatologicznych chłoniaka }\end{array}$ & 56 \\
\hline IIIA & T4 NO-2 MO BO-I & $\begin{array}{l}\text { erythroderma +/- lymphadenopathy without histopathologic evidence of lymphoma/ } \\
\text { erytrodermia, +/- limfadenopatia bez cech histopatologicznych chłoniaka }\end{array}$ & 54 \\
\hline IIIB & T4 NO-2 MO BI & $\begin{array}{l}\text { erythroderma }+/ \text { - lymphadenopathy without histopathologic evidence of lymphoma, } \\
\text { circulating tumour cells }<5 \% \text { /erytrodermia, +/- limfadenopatia bez cech } \\
\text { histopatologicznych chłoniaka, komórki nowotworowe we krwi }<5 \%\end{array}$ & 48 \\
\hline IVAI & TI-4 N0-2 MO B2 & $\begin{array}{l}\text { diverse cutaneous lesions, histopathologic evidence of lymphoma in the lymph nodes } \\
\text { with or without lymphadenopathy, circulating tumour cells }>5 \% / \text { różne zmiany } \\
\text { skórne, chłoniakowe zmiany histopatologiczne w węzłach chłonnych z limfadenopatią } \\
\text { lub bez, komórki nowotworowe we krwi }>5 \%\end{array}$ & 41 \\
\hline IVA2 & TI-4 N3 MO BO-2 & $\begin{array}{l}\text { diverse cutaneous lesions, histopathologic evidence of lymphoma in the lymph nodes } \\
\text { with or without lymphadenopathy, circulating tumour cells }>5 \% / \text { różne zmiany } \\
\text { skórne, chłoniakowe zmiany histopatologiczne w węzłach chłonnych z limfadenopatią } \\
\text { lub bez, komórki nowotworowe we krwi }>5 \%\end{array}$ & 23 \\
\hline IVB & $\begin{array}{l}\mathrm{TI}-4 \mathrm{NO}-3 \mathrm{MI} \\
\mathrm{BO}-2\end{array}$ & $\begin{array}{l}\text { histopathologic evidence of internal organ involvement/zajęcie narządów } \\
\text { wewnętrznych potwierdzone histopatologicznie }\end{array}$ & 18 \\
\hline
\end{tabular}

\section{CLINICAL PRESENTATION, DIFFERENTIAL DIAGNOSIS, TREATMENT AND PROGNOSIS}

The clinical presentation is diverse and depends on the type of lymphoma. The two most common primary cutaneous T-cell lymphomas, MF and SS, were the only types known for many years. However, over the past two decades there has been a great progress in diagnostic methods, resulting in the identification of new primary cutaneous lymphomas, both of the T-cell (PCTCL) and B-cell (PCBCL) types. Based on the clinical and histopathological features, and determination of cell immunophenotype, new lymphoma types have been identified and systematized in the current WHO classification (Tab. 1). In addition to lymphoma type, it also takes into account the frequency and 5-year survival rate. Many new types of PCLs are observed extremely rarely, and can be found in the literature only in the form of case reports. Consequently, there are no clear guidelines for the therapeutic management of such PCL forms. Contemporary therapeutic options are limited to the relief of symptoms without a possibility of a cure. The choice of the treatment method should be determined not only by its therapeutic efficacy but also safety and improvement in the quality of life.

\section{OBRAZ KLINICZNY, RÓŻNICOWANIE, LECZENIE I ROKOWANIE}

Obraz kliniczny jest zróżnicowany i uzależniony od typu chłoniaka. Przez wiele lat znane były jedynie dwa najczęściej występujące pierwotnie skórne rodzaje chłoniaków T-komórkowych: MF i SS. W ostatnich dwóch dekadach dokonał się ogromny postęp w zakresie metod diagnostycznych, które umożliwiły wyodrębnienie nowych typów chłoniaków pierwotnie skórnych zarówno T- (PCTCL), jak i B- (PCBCL) komórkowych. Na podstawie obrazu klinicznego, histopatologicznego oraz immunofenotypu komórek wyodrębniono nowe typy chłoniaków, które usystematyzowano w obecnie obowiązującej klasyfikacji WHO (tab. 1). Uwzględniono w niej nie tylko rodzaj chłoniaka, lecz także częstość występowania i 5-letnie przeżycia. Wiele nowych typów chłoniaków pierwotnie skórnych ujawnia się niezwykle rzadko, a w piśmiennictwie dostępne są jedynie ich kazuistyczne opisy. Dlatego też nie ma jednoznacznych wytycznych dotyczących postępowania terapeutycznego w tych postaciach. Możliwości współczesnych metod terapii ograniczają się do zmniejszenia nasilenia objawów, bez wyleczenia chorego - przy wyborze metody należy kierować się nie tylko jej skutecznością, lecz także bezpieczeństwem i poprawą jakości życia. 
Table 4. Modified Severity Weighted Assessment Tool (mSWAT) and evaluation of the progression/remission of skin lesions (rule of the palm: the surface area of the patient's palm with fingers equals $1 \%$ of the body surface) [I 4$]$

Tabela 4. Kryteria modified Severity Weighted Assessment Tool (mSWAT) i ocena progresji lub remisji zmian skórnych (powierzchnia dłoni i palców pacjenta to $1 \%$ powierzchni ciała) [14]

\begin{tabular}{|c|c|c|c|c|}
\hline \multirow[t]{2}{*}{ Body region/Region ciała } & \multirow[t]{2}{*}{$\begin{array}{l}\text { \%BSA in body region/BSA } \\
\text { w obrębie regionu (\%) }\end{array}$} & \multicolumn{3}{|c|}{$\begin{array}{l}\text { Assessment of involvement in patient's skin/ } \\
\text { Ocena zmian skórnych }\end{array}$} \\
\hline & & $\begin{array}{l}\text { Patches*/Zmiany } \\
\text { rumieniowe* }\end{array}$ & $\begin{array}{l}\text { Plaques**/Zmiany } \\
\text { naciekowe** }\end{array}$ & $\begin{array}{l}\text { Tumours***l } \\
\text { Guzy*** }\end{array}$ \\
\hline head/głowa & 7 & & & \\
\hline neck/szyja & 2 & & & \\
\hline anterior trunk/tułów - przód & 13 & & & \\
\hline arms/ramiona & 8 & & & \\
\hline forearms/przedramiona & 6 & & & \\
\hline hands/ręce & 5 & & & \\
\hline posterior trunk/tułów - tył & 13 & & & \\
\hline buttocks/pośladki & 5 & & & \\
\hline thighs/uda & 19 & & & \\
\hline legs/podudzia & 14 & & & \\
\hline feet/stopy & 7 & & & \\
\hline groin/pachwiny & 1 & & & \\
\hline $\begin{array}{l}\text { subtotal of lesions (\% BSA)/suma } \\
\text { zmian w kolumnie (\% BSA) }\end{array}$ & 100 & A & $\mathrm{B}$ & C \\
\hline weighting factor/współczynnik & $\mathrm{N} / \mathrm{A} / \mathrm{ND}$ & $\times 1$ & $\times 2$ & $\times 4$ \\
\hline $\begin{array}{l}\text { subtotal of lesions }(\% \mathrm{BSA}) \times \\
\text { weighting factor/suma zmian } \\
(\% \mathrm{BSA}) \times \text { współczynnik }\end{array}$ & $\mathrm{N} / \mathrm{A} / \mathrm{ND}$ & $A \times 1$ & $\mathrm{~B} \times 2$ & $C \times 4$ \\
\hline
\end{tabular}

*For skin, patch indicates any size lesion without any induration or significant elevation above the surrounding uninvolved skin. Excessive poikiloderma should be noted. ***For skin, plaque indicates any size lesion that is elevated or indurated. Crusting, ulceration, or poikiloderma may be present. ****For skin, tumour indicates any solid or nodular lesion $\geq 1 \mathrm{~cm}$ in diameter with evidence of deep infiltration in the skin and/or vertical growth. For erythroderma, only patch and plaque columns should be considered. mSWAT score equals the sum total of each column line: $m S W A T=[(A \times 1)+(B \times 2)+(C \times 4)]$; \%BSA - \% body surface area; N/A - not applicable.

*Zmiana rumieniowa oznacza każdą zmianę skórnq (niezależnie od wielkości), która nie jest w istotny sposób uniesiona i twarda. Należy odnotować również nadmiernq poikilodermię. ***Zmiana naciekowa oznacza każdq zmianę skórnq (niezależnie od wielkości), która jest uniesiona lub twarda. Możliwa obecność strupów, owrzodzeń, poikilodemii. ****Guz oznacza zmianę litq̨ o średnicy $\geq 1 \mathrm{~cm}$ wrastającq w głąb skóry i/lub wyrastającą ponad jej poziom. W przypadku erytrodermii należy uwzględnić tylko kolumny dotyczące zmian rumieniowych i naciekowych. Wspótczynnik mSWAT oznacza sumę wartości poszczególnych kolumn z ostatniego wersu: mSWAT $=[(A \times 1)+(B \times 2)+(C \times 4)]$; \%BSA - procent powierzchni ciała, ND - nie dotyczy.

\section{PRIMARY CUTANEOUS CANCERS DERIVED FROM MATURE T AND NK CELLS}

\section{Subcutaneous panniculitis-like T-cell lymphoma}

Subcutaneous panniculitis-like T-cell lymphoma (SPTCL) occurs both in adults and in children, with same frequency in both sexes. It presents as solitary or multiple tumours and/or infiltrates resembling subcutaneous panniculitis, located on the extremities or trunk, less commonly the face. While resolving, tumours may leave behind adipose tissue atrophy. The skin lesions are often accompanied by elevated body temperature, fatigue, body weight loss, peripheral blood cytopaenia and increased transaminase levels in the blood. SPTCL may be complicated by haemophagocytic syndrome (HPS)

\section{PIERWOTNE NOWOTWORY SKÓRNE Z DOJRZAŁYCH KOMÓREK T I NK}

\section{Chłoniak z komórek T tkanki podskórnej typu zapalenia tkanki podskórnej}

Chłoniak z komórek $\mathrm{T}$ tkanki podskórnej typu zapalenia tkanki podskórnej (subcutaneous panniculitis-like T-cell lymphoma - SPTCL) występuje u dorosłych i dzieci, z taką samą częstością u obu płci. Objawia się pojedynczymi lub mnogimi guzami i/lub naciekami typu zapalenia tkanki podskórnej w obrębie kończyn, tułowia i rzadziej twarzy. Guzy, ustępując, mogą pozostawiać zaniki tkanki tłuszczowej. Zmianom towarzyszą: podwyższona ciepłota ciała, uczucie zmęczenia, utrata masy ciała, cytopenia we krwi 
Table 5. Modified Severity Weighted Assessment Tool (mSWAT) evaluation of response to treatment based on the patient's condition $[5-8,14]$

Tabela 5. Ocena odpowiedzi na leczenie na podstawie stanu chorego wg kryteriów modified Severity Weighted Assessment Tool (mSWAT) $[5-8,14]$

\begin{tabular}{|c|c|}
\hline Definition/Definicja & Response/Odpowiedź \\
\hline $\begin{array}{l}\text { complete response }(C R) / \\
\text { całkowita remisja (CR) }\end{array}$ & 100\% clearance of skin lesions*/I00-procentowe ustąpienie zmian skórnych** \\
\hline $\begin{array}{l}\text { partial response (PR)/częściowa } \\
\text { odpowiedź (PR) }\end{array}$ & $\begin{array}{l}\text { 50-99\% clearance of skin lesions from baseline without new tumours (T3) in patients with TI, } \\
\text { T2 or T4 (only skin disease)/ustąpienie zmian skórnych w 50-99\% mSWAT w stosunku do stanu } \\
\text { wyjściowego, bez nowych guzów (T3) w stadiach TI, T2 lub T4 (choroba ograniczona do skóry) }\end{array}$ \\
\hline $\begin{array}{l}\text { stable disease (SD)/stabilizacja } \\
\text { choroby }(\mathrm{SD})\end{array}$ & $\begin{array}{l}<50 \% \text { clearance of skin lesions (mSWAT) from baseline or appearance of new skin lesions < } 25 \% \\
\text { (mSWAT) in relation to baseline, without new tumours (T3) in patients with TI, T2 or T4 (only skin } \\
\text { disease)/ustąpienie zmian skórnych < 50\% mSWAT lub pojawienie się nowych zmian skórnych } \\
\text { w liczbie nieprzekraczającej } 25 \% \text { mSWAT w stosunku do stanu wyjściowego, bez nowych guzów } \\
\text { (T3) w stadiach TI, T2 lub T4 (choroba ograniczona do skóry) }\end{array}$ \\
\hline $\begin{array}{l}\text { progressive disease }(\mathrm{PD})^{* * *} / \\
\text { progresja choroby }(\mathrm{PD})^{* * *}\end{array}$ & $\begin{array}{l}\geq 25 \% \text { increase in skin disease from baseline or new tumours (T3) in patients with TI, T2, or T4 } \\
\text { (only skin disease), or loss of response: in those with complete or partial response, increase of } \\
\text { skin score of greater than the sum of nadir plus } 50 \% \text { baseline score/pojawienie się nowych zmian } \\
\text { skórnych na obszarze przekraczającym } 25 \% \text { mSWAT lub nowe guzy (T3) u pacjentów w stadiach } \\
\text { TI, T2 lub T4 (choroba ograniczona do skóry), lub utrata odpowiedzi na leczenie: u pacjentów } \\
\text { z CR lub PR, u których mSWAT osiągnął wartość wyższą niż nadir plus 50\% wartości wyjściowej }\end{array}$ \\
\hline relapse/nawrót & any disease recurrence in those with complete response/jakiekolwiek zmiany u pacjenta z CR \\
\hline
\end{tabular}

which leads to progression of the disease (in approximately $15 \%$ of patients) and represents an unfavourable prognostic factor. Over $20 \%$ of patients may have a coexisting systemic connective tissue disease, typically systemic lupus erythematosus (SLE). The dominant histopathological feature is a subcutaneous infiltrate composed of small, medium-sized and large cytotoxic lymphocytes with the phenotype $\alpha \beta C D 3+C D 4-C D 8+$, and numerous macrophages. There are no recognized therapeutic standards. Prednisone at a dose of 30-50 mg/day, in combination with small doses of methotrexate (MTX) in refractory cases, has been shown to be therapeutically beneficial. On account of the risk of lymphoproliferation associated with the therapy based on cyclosporine $\mathrm{A}$, the drug is not indicated in SPTLC, contrary to previous literature reports (in the authors' view, the use of the drug in SPTLC should be forbidden). HPS requires chemotherapy based on the CHOP regimen (cyclophosphamide, doxorubicin, vincristine, prednisone) and/or radiotherapy. In terms of prognosis, the 5-year survival rate is $91 \%$ in patients without HPS and $46 \%$ in patients with HPS. In cases of CHOP-resistant HPS, the following therapies are used: cladribine, DHAP regimen (dexamethasone, cytarabine, cisplatin), alemtuzumab and transplantation of hematopoietic stem cells [5-8, 15-18]. obwodowej oraz wzrost stężenia transaminaz we krwi. Nowotwór ten może być powikłany zespołem hemofagocytarnym (hemophagocytic syndrome - HPS), którego wystąpienie prowadzi do progresji choroby (ok. 15\% chorych) i jest złym czynnikiem rokowniczym. U ponad $20 \%$ chorych współistnieje układowa choroba tkanki łącznej, najczęściej układowy toczeń rumieniowaty (SLE). W obrazie histopatologicznym przeważa naciek w tkance podskórnej złożony z limfocytów cytotoksycznych małych, średnich i dużych o fenotypie $\alpha \beta$ CD3+CD4-CD8+ oraz licznych makrofagów. W leczeniu nie ma uznanych standardów terapeutycznych. Podkreśla się korzystny efekt prednizonu w dawce 30-50 mg/dobę, w przypadkach opornych w skojarzeniu z małymi dawkami metotreksatu (MTX). Ze względu na ryzyko limfoproliferacji podczas terapii cyklosporyną A lek ten, pomimo wcześniejszych doniesień z piśmiennictwa, nie jest zalecany w SPTCL (zdaniem autorów jego stosowanie $\mathrm{w}$ SPTCL powinno być zabronione). W przypadku HPS konieczna jest chemioterapia wg schematu CHOP (cyklofosfamid, doksorubicyna, winkrystyna, prednizon) i/lub radioterapia - 5 lat przeżywa 91\% chorych bez HPS i $46 \%$ z HPS. W przypadkach z HPS opornych na CHOP stosuje się m.in. kladrybinę, schemat DHAP (deksametazon, cytarabina, cisplatyna), alemtuzumab, przeszczepienie krwiotwórczych komórek macierzystych [5-8, 15-18]. 
Table 6. Proposed algorithm for the diagnosis of early mycosis fungoides (early form $\geq 4$ score) including clinical, histologic and immunopathologic criteria, and clonal gene rearrangement $[19,20]$

Tabela 6. Algorytm diagnostyki wczesnych postaci ziarniniaka grzybiastego (mycosis fungoides) (wczesna postać $\geq 4$ pkt) obejmujq̨cy kryteria kliniczne, histologiczne, immunopatologiczne oraz klonalną rearanżację genów [19, 20]

\begin{tabular}{|c|c|c|c|}
\hline $\begin{array}{l}\text { Characteristics/ } \\
\text { Charakterystyka }\end{array}$ & Basic criteria/Kryteria główne & $\begin{array}{c}\text { Additional criteria/Kryteria } \\
\text { dodatkowe }\end{array}$ & Score/Punktacja \\
\hline clinical/obraz kliniczny & $\begin{array}{l}\text { persistent and/or progressive } \\
\text { patches/thin plaques/nieustępujące } \\
\text { lub postępujące zmiany plamisto- } \\
\text {-rumieniowe (patches) lub } \\
\text { naciekowe (plaques) }\end{array}$ & $\begin{array}{l}\text { - Non-sun-exposed location/ } \\
\text { zmiany zlokalizowane na skórze } \\
\text { nieeksponowanej na UV } \\
\text { - size/shape variation/zmiany } \\
\text { o zmiennym kształcie } \\
\text { i rozmiarach } \\
\text { - poikiloderma/poikilodermia }\end{array}$ & $\begin{array}{l}\text { - basic criteria and two additional } \\
\text { criteria - } 2 \text { points/obecne } \\
\text { kryterium główne i } 2 \text { kryteria } \\
\text { dodatkowe - } 2 \text { pkt } \\
\text { - basic criterion and one additional } \\
\text { criterion - I point/ obecne } \\
\text { kryterium główne i I kryterium } \\
\text { dodatkowe - I pkt }\end{array}$ \\
\hline $\begin{array}{l}\text { histologic/zmiany } \\
\text { histologiczne }\end{array}$ & $\begin{array}{l}\text { superficial lymphoid infiltrate/ } \\
\text { powierzchowny naciek } \\
\text { limfocytarny }\end{array}$ & $\begin{array}{l}\text { • epidermotropism without } \\
\text { spongiosis/epidermotropizm bez } \\
\text { cech spongiozy } \\
\text { - lymphoid atypia (cells with } \\
\text { enlarged, hyperchromatic } \\
\text { nuclei and irregular or } \\
\text { cerebriform nuclear } \\
\text { contours)/atypia limfocytów } \\
\text { (komórki z powiększonymi, } \\
\text { hiperchromatycznymi jądrami } \\
\text { lub jądrami o nieregularnym, } \\
\text { mózgoksztaltnym obrysie) }\end{array}$ & $\begin{array}{l}\text { - basic criterion and two additional } \\
\text { criteria - } 2 \text { points/obecne } \\
\text { wszystkie cechy - } 2 \text { pkt } \\
\text { - basic criterion and one additional } \\
\text { criterion - I point/obecne } \\
\text { kryterium gtówne i I kryterium } \\
\text { dodatkowe - I pkt }\end{array}$ \\
\hline $\begin{array}{l}\text { molecular/zaburzenia } \\
\text { molekularne }\end{array}$ & $\begin{array}{l}\text { clonal TCR gene rearrangement/ } \\
\text { klonalna rearanżacja genu TCR }\end{array}$ & - & I point for clonality/tak - I pkt \\
\hline $\begin{array}{l}\text { immunopathologic/ } \\
\text { zaburzenia } \\
\text { immunopatologiczne }\end{array}$ & $\begin{array}{l}\text { - presence of CD2, CD3 and/or } \\
\text { CD5 antigens on less than 50\% } \\
\text { of T cells/obecność antygenów } \\
\text { CD2, CD3 i/lub CD5 na mniej } \\
\text { niż 50\% komórek T } \\
\text { - presence of CD7 antigen on less } \\
\text { than I0\% of T cells/obecność } \\
\text { antygenu CD7 na mniej niż I0\% } \\
\text { komórek T } \\
\text { - discordance of CD2, CD3, } \\
\text { CD5 or CD7 antigen expression } \\
\text { on cutaneous T cells in } \\
\text { the epidermis and dermis } \\
\text { (no epidermal expression)/ } \\
\text { niezgodność pod względem } \\
\text { ekspresji antygenów CD2, CD3, } \\
\text { CD5 lub CD7 na skórnych } \\
\text { komórkach T w naskórku } \\
\text { i skórze (brak ekspresji } \\
\text { w naskórku) }\end{array}$ & & \\
\hline
\end{tabular}

\section{Mycosis fungoides}

Mycosis fungoides (MF) typically affects adults (median age at diagnosis: 55-60 years), with a slight predominance of men over women. Cutaneous lesions in MF are accompanied by pruritus of varying severity. The initial patch stage (MF I) presents with erythematous or eczema-type skin lesions located primarily on non-sun-exposed body parts. In this phase the disease is often undiagnosed and skin lesions are identified either as eczema, atopic dermatitis or psoriasis vulgaris. In 2005 researchers from the International Society of Cutaneous Lymphoma

\section{Ziarniniak grzybiasty}

Ziarniniak grzybiasty występuje głównie u dorosłych (mediana wieku: 55-60 lat), nieznacznie częściej u mężczyzn. Zmianom skórnym towarzyszy świąd o różnym stopniu nasilenia. W MF I (stadium rumieniowe) stwierdza się zmiany rumieniowe lub wypryskowate, głównie na nieeksponowanych na słońce częściach ciała. Na tym etapie choroba bywa nierozpoznana, a zmiany skórne są kwalifikowane jako wyprysk, atopowe zapalenie skóry lub łuszczyca zwyczajna. W 2005 r. badacze ISCL (International Society of Cutaneous Lymphoma) opracowali algorytm ułatwia- 
(ISCL) developed an algorithm which facilitates the diagnosis of the disease at this stage (Tab. 6). As the disease progresses, MF enters the plaque stage (IBIIA) characterized by flat infiltrates among patch-type lesions typical for stage IA. The lesions may spread, ultimately covering over $80 \%$ of the skin's surface area (erythroderma, MF III). The tumour stage (MF IIB) is marked by the presence of livid-red tumours with a tendency to disintegrate (in infiltrative lesions or de novo). The lymph nodes and/or internal organs may also be affected in advanced stages of the disease (MFIV).

The histopathological features differ depending on the stage. The patches occurring in MF stage IA are uncharacteristic, as in inflammations. Plaques seen in MF stages IB-IIA contain small and middle-sized T lymphocytes with irregular hyperchromatic nuclei (nucleus cerebriformis) arranged in the sub-epidermal layer, with epidermotropism and Pautrier's microabscesses. In MF stage IIB the plaques containing cancerous lymphocytes are dense, often without epidermotropism, and involve deep dermal layers including the subcutaneous tissue. Late stages of MF may present with the loss of antigenic characteristics of $\mathrm{T}$ lymphocytes and the emergence of CD30+ antigen expression [5-11, 19, 20].

The clinical presentation of the disease may vary significantly, however classical manifestations are the most common. Thirty one variants of mycosis fungoides have been described to date. In addition to the classical form of the disease, the most common variants include folliculotropic mycosis fungoides, pagetoid reticulosis and granulomatous slack skin. The three forms are referred to as variants of MF and additionally specified in accordance with the WHO classification (Tab. 1). The variants have been differentiated on account of dissimilarities in clinical/ pathological and biological/behavioural features. All variants have their characteristic clinical presentations and recommended variant-specific therapeutic regimens. In the folliculotropic variant the skin lesions manifest as grouped follicular papules with follicular keratosis superimposed on erythematous macules, hard infiltrated plaques or occasionally tumours - or soft infiltrative lesions and alopecic foci. A common manifestation is mucinous follicular degeneration. The lesions are located primarily on the face and upper trunk, neck and scalp, giving rise to clinical suspicions of acne. The recommended treatment modality is total skin electron beam (TSEB) therapy. Patients with this form of MF do not respond to mechlorethamine and have a weaker response to photochemotherapy (psoralen ultra-violet A - PUVA) in monotherapy. In some cases an improvement can be achieved by combining PUVA with retinoids or interferon- $\alpha$ (IFN- $\alpha)$. Persistent tumours require an jący rozpoznanie schorzenia na tym etapie (tab. 6.). Wynikiem progresji choroby jest przejście MF w stadium IB-IIA (stadium naciekowe), dla którego typowe są płaskie nacieki wśród zmian rumieniowych charakterystyczne dla stadium IA. Zmiany mogą się rozszerzać, zajmując ponad $80 \%$ powierzchni skóry (erytrodermia, MF III). Okres MF IIB (stadium guzowate) cechuje się występowaniem sinoczerwonych guzów $\mathrm{z}$ tendencją do rozpadu (w zmianach naciekowych lub de novo). W stadiach zaawansowanych zajęte są węzły chłonne i/lub narządy wewnętrzne (MFIV).

Obraz histopatologiczny różni się w poszczególnych stadiach. W MF IA zmiany są niecharakterystyczne - jak w stanie zapalnym. W MF IB-IIA nacieki złożone są z małych i średnich limfocytów T o hiperchromatycznych i nieregularnych jądrach (nucleus cerebriformis) układających się podnaskórkowo, z epidermotropizmem i mikroropniami Pautriera. W MF IIB nacieki z nowotworowych limfocytów są gęste, często bez epidermotropizmu, obejmują głębokie warstwy skóry, w tym tkankę podskórną. W późnych stadiach MF może dochodzić do zanikania cech antygenowych limfocytów T i pojawiania się ekspresji antygenu CD30+ [5-11, 19, 20].

Obraz kliniczny choroby może być bardzo zróżnicowany, chociaż najczęściej występują zmiany klasyczne. Opisano 31 odmian MF. Najczęstsze postacie, oprócz klasycznej, to postać folikulotropowa, typu siatkowicy pagetoidalnej oraz typu skóry obwisłej i ziarniniakowej. Te trzy postacie przyjęto określać terminem wariantów MF i dodatkowo wyszczególniać jak w klasyfikacji WHO (tab. 1). Powodem wyodrębnienia jest odmienny obraz kliniczno-patologiczny i biologiczno-behawioralny. Warianty mają charakterystyczny obraz kliniczny, a także typowy dla każdej postaci schemat zalecanej terapii. W postaci folikulotropowej zmiany skórne mają charakter zgrupowanych przymieszkowych grudek z rogowaceniem przymieszkowym na podłożu rumieniowych plam, twardych nacieczonych tarczek, czasem guzów lub miękkich, naciekowych ognisk oraz ognisk wyłysienia. W postaci tej często występuje zwyrodnienie mucynowe mieszka włosowego. Wykwity lokalizują się najczęściej na twarzy, w górnych częściach tułowia, na karku i owłosionej głowie, klinicznie nasuwając podejrzenie trądziku. W leczeniu rekomenduje się napromienianie elektronami całego ciała (total skin electron beam radiation - TSEB). Ta postać nie odpowiada na mechloretaminę i słabiej na fotochemioterapię (psoralen ultra-violet A - PUVA) w monoterapii. Czasami poprawę można uzyskać, stosując w skojarzeniu PUVA-terapię z retinoidami lub interferonem $\alpha$ (IFN- $\alpha$ ). W przypadku przetrwałych guzów konieczna jest dodatkowa dawka radio- 
additional dose of radiotherapy, however full clinical remission is difficult to achieve [5-11, 21, 22].

It used to be thought that folliculotropic mycosis fungoides was associated with poorer prognosis (baseline prognosis is the same as in stage IIB of classical MF). It is currently known that the prognosis in cases with one erythematous or infiltrative lesion is as good as in the classical form of MF. In the pagetoid reticulosis variant the skin lesions typically present as a solitary erythematous/exfoliative plaque, reddish brown in colour and sharply marginated, located on the extensor surfaces of the extremities, mainly the legs. The treatment of choice includes topical steroids and mechlorethamine. Other recommended modalities are radiotherapy or surgical excision. Granulomatous slack skin is a variant characterized by the presence of pendulous lax skin folds in the axillae and groins, with a granulomatous infiltrate of clonal T cells. The variant is extremely rare and in one third of cases there is an association with Hodgkin's disease. The recommended treatment in this form of MF is radiotherapy [4-8].

Since the first descriptions of classical MF in 1806 and SS in 1938, the range of therapeutic options has been expanding from topical glucocorticosteroids to the most advanced drug treatments based on molecular studies which make it possible to defer chemotherapy as a treatment modality that typically produces no cure but causes multiple adverse effects. Total cure is not possible, and therapy is aimed at achieving clinical remission which is incomplete in the majority of cases. Some patients do not demonstrate clinical progression according to TNMB (Tab. 2 and 3), however in others progression occurs despite treatment, and its rate is individually variable among patients. Consequently, patients diagnosed with MF/SS should receive "palliative" treatment in stages depending on the progression of the disease (Tab. 7) [23]. Clinical evaluation of therapeutic outcomes is sufficient in grade IA (resolution of erythe$\mathrm{ma})$, however histopathological evaluation should be considered at more advanced stages. MF stages IA-IIA should be treated with the least toxic dermatological therapy leading to disease remission. As the risk of disease progression is low $(10 \%$ over a 10 -year period) and the survival rate is the same as in the general population, a watch-and-wait approach is acceptable as a treatment strategy, provided that patients are regularly monitored (evidence-based medicine level 4 - EBM 4). This is because there is no evidence that the initiation of treatment at an early stage of the disease halts the progression. Solitary erythematous lesions are usually treated with class I topical glucocorticosteroids (betamethasone dipropionate, mometasone furoate, clobetasol propionate) (EBM 3). Used twice a day, terapii, jednak trudno jest uzyskać pełną remisję kliniczą [5-11, 21, 22].

Dawniej uważano, że postać folikulotropowa charakteryzuje się gorszym rokowaniem (prognoza na początku choroby jest taka jak w stadium IIB klasycznego MF). Obecnie wiadomo, że postacie z jednym ogniskiem rumieniowym lub naciekowym rokują równie dobrze jak klasyczna postać MFI. W postaci typu siatkowicy pagetoidalnej zmiany skórne mają zwykle charakter pojedynczego, czerwonobrązowego, ostro odgraniczonego ogniska rumieniowo-złuszczającego zlokalizowanego na wyprostnych powierzchniach kończyn, głównie dolnych. Leczeniem z wyboru są miejscowe steroidy i mechloretamina. Zaleca się także radioterapię lub usunięcie chirurgiczne. Postać typu skóry obwisłej i ziarniniakowej charakteryzuje się rozwojem wiotkich, obwisłych fałdów skóry w dołach pachowych i pachwinowych, z ziarniniakowym naciekiem $z$ klonalnych komórek T. Jest postacią występującą ekstremalnie rzadko, w 1/3 przypadków współwystępuje z chorobą Hodgkina. Zalecaną metodą leczenia tej postaci MF jest radioterapia [4-8].

Od pierwszego opisu klasycznej postaci MF w $1806 \mathrm{r}$. iSS w 1938 r. liczba możliwości terapeutycznych zwiększała się, począwszy od leczenia miejscowego glikokortykosteroidami do najnowocześniejszych leków zaprojektowanych dzięki badaniom molekularnym, pozwalających na odroczenie chemioterapii, która najczęściej nie prowadzi do wyleczenia, a jest obciążona licznym działaniami niepożądanymi. Nie można uzyskać całkowitego wyleczenia, tylko remisje klinicznie - w większości przypadków niepełne. U niektórych chorych nie obserwuje się postępu klinicznego zgodnie z klasyfikacją TNMB (tab. 2 i 3), $\mathrm{u}$ innych pomimo leczenia progresja jest widoczna, a jej tempo osobniczo zróżnicowane. Stąd też chorych z rozpoznaniem MF/SS powinno się traktować jak pacjentów „paliatywnych” i w leczeniu postępować etapowo, zgodnie z postępem choroby (tab. 7) [23]. Kliniczna ocena efektów terapii jest wystarczająca w stopniu IA (ustępowanie rumienia), natomiast w stadiach bardziej zaawansowanych należy rozważyć weryfikację histopatologiczną. W MF IA-IIA zaleca się terapię dermatologiczną jak najmniej toksyczną, ale prowadzącą do remisji. Ze względu na małe ryzyko progresji (10\% w ciągu 10 lat) i czas przeżycia taki sam jak przeciętny w populacji ogólnej dopuszcza się postawę wyczekującą bez leczenia (watch and wait), pod warunkiem ścisłej, regularnej obserwacji (poziom dowodów evidence-based medicine 4 (EBM 4)). Wynika to z braku dowodów, że wprowadzenie leczenia we wczesnym stadium hamuje progresję choroby. W przypadku pojedynczych zmian rumieniowych najczęściej stosuje się miejscowo glikokortykosteroidy klasy I (dipropionian betametazonu, pirośluzan mometazonu, propionian klobetazolu) (EBM 3). Za- 
Table 7. Treatment of mycosis fungoides

Tabela 7. Leczenie ziarniniaka grzybiastego

\section{Premycotic stage/Stadium premycoticum}

- topical glucocorticosteroids with the highest potency (GCs); UVB3 I I/miejscowo glikokortykosteroidy o największej sile działania (GKS); UVB3। I

- if not effective, PUVA/jeśli brak skuteczności, PUVA

\section{Stages IA-IIA (patch-plaque)/Stadium IA-IIA (faza rumieniowo-tarczkowa)}

- topical glucocorticosteroids (TIA-T2A)/miejscowo GKS (TIA-T2A)

- UVB (TIA-T2A)

- phototherapy: UVB3 I I (patch), PUVA (including PUVA-bath) (plaque)/fototerapia: UVB 3 I I (gdy zmiany rumieniowe), PUVA

(w tym PUVA-bath) (gdy zmiany naciekowe)

- localised RT (for localised MF including pagetoid reticulosis)/miejscowo radioterapia na pojedyncze ogniska MF, w tym pagetoid reticulosis

- mechlorethamine/mechloretamina

Second-line treatment/Druga linia leczenia

- topical bexarotene gel (on limited patches and moderately infiltrated plaques as second-line treatment)/beksaroten żel miejscowo

(na ograniczone rumienie i umiarkowanie nacieczone tarczki jako druga linia leczenia)

- systemic IFN- $\alpha$, more commonly initial treatment with low dose MTX (5-25 mg/week), retinoids (isotretinoin as in acne, acitretin as in psoriasis or bexarotene 300 mg/m²/day)/ogólnie: IFN- $\alpha$, częściej początkowo leczenie MTX małymi dawkami (5-25 mg

tygodniowo), retinoidy (izotretynoina jak w acne, acytretyna jak w łuszczycy lub beksaroten $300 \mathrm{mg} / \mathrm{m}^{2} /$ dobę)

- TSEB (mainly T2B)/TSEB (głównie T2B)

\section{Stage IIB (tumour phase)/Stadium IIB (faza guzowata)}

- systemic therapy: retinoids or IFN- $\alpha$ also in combination with PUVA/terapia ogólna: retinoidy lub IFN- $\alpha$, także w skojarzeniu z PUVA

- TSEB

- MTX (doses as above, less commonly up to 75 mg/week)/MTX (dawki jw., rzadziej do 75 mg tygodniowo)

- monochemotherapy (gemcitabine, pegylated liposomal doxorubicine)/monochemioterapia (gemcitabina, pegylowana liposomalna doksorubicyna)

- RT (used as add-on treatment in combination with skin directed therapies)/RT (jako terapia dodana do leczenia ogólnego w skojarzeniu z leczeniem ukierunkowanym na skórę)

Second-line treatment/Druga linia leczenia

- polichemotherapy (CHOP)/polichemioterapia (CHOP)

- allogeneic stem cell transplantation (restricted to exceptional cases)/allogeniczny przeszczep komórek krwiotwórczych (rzadko, w uzasadnionych przypadkach)

\section{Stage III (erythroderma)/Stadium III (erytrodermia)}

- systemic therapy: retinoids or IFN- $\alpha$ also in combination with PUVA/terapia ogólna: retinoidy lub IFN- $\alpha$, także w skojarzeniu z PUVA

- ECP (alone or in combination with skin directed and other systemic therapies - mainly in BI)/ECP (izolowana lub w skojarzeniu z terapią celowaną na skórę lub inną terapią ogólną - szczególnie w BI)

- MTX (doses as above, less commonly up to 75 mg/week)/MTX (dawki jw., rzadziej do 75 mg tygodniowo)

-TSEB

Second-line treatment/Druga linia leczenia

- monochemotherapy (gemcitabine, pegylated liposomal doxorubicine)/monochemioterapia (gemcitabina, pegylowana liposomalna doksorubicyna)

- allogeneic stem cell transplantation (restricted to exceptional cases)/allogeniczny przeszczep komórek krwiotwórczych (w uzasadnionych przypadkach)

\section{Stage IV (lymph node and internal organ involvement)/Stadium IV (zajęte węzły chłonne, narządy wewnętrzne)}

- chemotherapy (gemcitabine, pegylated liposomal doxorubicine, CHOP and CHOP-like polychemotherapies)/chemioterapia (gemcitabina, pegylowana liposomalna doksorubicyna, CHOP i inne, podobne do CHOP złożone chemioterapie)

- radiotherapy (TSEB alone or in combination with systemic therapies)/radioterapia (TSEB izolowana lub w skojarzeniu ze złożonym

leczeniem ogólnym)

- alemtuzumab (mainly in B2)/alemtuzumab (szczególnie w B2)

- allogeneic stem cell transplantation/allogeniczny przeszczep komórek krwiotwórczych

$C H O P$ - cyclophosphamide + hydroxydaunomycin (doxorubicin) = Oncovin (vincristine) + prednisone, ECP - extracorporeal photopheresis, MTX - methotrexate, IFN - interferon, RT - localized radiotherapy, TSEB - total skin electron beam/CHOP - cyklofosfamid + hydroksydaunomycyna (doksorubicyna) = Oncovin (winkrystyna) + prednizon, ECP - fotoforeza pozaustrojowa, MTX - metotreksat, IFN - interferon, RT - miejscowa radioterapia, TSEB - napromieniowanie elektronami całego ciała. 
they make it possible to achieve remission in $94 \%$ of all cases. Second-line therapy is bexarotene 1\% gel (response noted in 44-63\% of cases, time-to-remission: 28-504 days), unfortunately not readily available in Poland, or alternatively tazarotene used on an off-label basis. Other topical treatments recommended for stages IA and IB (imported on a named-patient basis authorized by the Polish Ministry of Health) include mechlorethamine as $10-20 \mathrm{mg} / \mathrm{ml}$ solution or $0.02 \%$ gel or ointment used once daily (mSWAT response $46.9 \%$ vs. $46.2 \%$ ) (EBM 2) and carmustine as $20-40 \%$ ointment or $10 \mathrm{mg} / 60 \mathrm{ml} 95 \%$ alcohol solution once a day. Phototherapy can be used in MF stages IA-IIA (EBM 2). Erythematous lesions can be treated with UVB311 (there is a shift away from broad-spectrum UVB), and erythematous infiltrative lesions - with PUVA. PUVA, comprising 8-methoxypsoralen and UVA irradiation, should be applied 2-3 times a week until skin lesions resolve (3-4 months when remission is achieved, then at a reduced frequency for another 2-3 months). Complete remissions (CR) are achieved in $58-83 \%$, and partial remissions (PR) in $95 \%$ of patients. The average duration of remission is 43 months. According to the EORTC guidelines (2017), the treatment regimen should be similar to that used in psoriasis [5-8].

A less common, though also recommended, form of phototherapy in MF is UVA1 irradiation. This type of radiation treatment operates by stimulating the early phase of apoptosis of lymphocytes and proliferating mastocytes via different mechanisms than those in UVB or PUVA. UVA1 radiation increases the production of superoxide anions and singlet oxygen, thus stimulating depolarization of the mitochondrial membrane and activation of T lymphocytes. UVA1 has also been shown to inhibit the synthesis of tumor necrosis factor $\alpha$ (TNF- $\alpha$ ), interlekin-12 (IL-12), interferon $\alpha(\mathrm{IFN}-\alpha)$ and intercellular adhesion molecule 1 (ICAM-1), and reduce the concentrations of IL-6 and IL-8. Recent studies have also demonstrated that UVA1 inhibits the activity of calcineurin in vivo and in vitro, and uses the same signalling pathway in the skin as calcineurin inhibitors. Regardless of the stage of MF, UVA1 treatment is administered in 10-35 sessions per course at medium or high daily doses (40-80 J/ $\mathrm{cm}^{2}$ and 80-130 J/ $\mathrm{cm}^{2}$, respectively) [24-26]. The efficacy of PUVA or UVA1 phototherapy can be increased by combining it with retinoids (acitretin, isotretinoin), rexinoids - bexarotene at $300 \mathrm{mg} / \mathrm{m}^{2}$ bosy surface area (BSA) p.o. or IFN- $\alpha$. The combination of PUVA with IFN- $\alpha$ or acitretin with IFN- $\alpha$ results in the same complete response rates $(90.5 \%$ vs. $90 \%$, respectively), however complete remission is achieved more frequently in the former case $(70 \%$ vs. $38 \%$ ). Also, other retinoids in combination with IFN- $\alpha$ have not been shown to be superior to acitre- stosowanie dwa razy dziennie pozwala na uzyskanie remisji w 94\%. Metodą drugiej linii jest beksaroten w żelu 1\% (odpowiedź w 44-63\%, czas do remisji 28-504 dni), niestety w Polsce trudno osiągalny, ewentualnie tazaroten - stosowany off-label. Inne leki miejscowe do stosowania w stadium IA i IB (sprowadzane na wniosek do Ministerstwa Zdrowia o import docelowy leku) to mechloretamina - roztwór $10-20 \mathrm{mg} / \mathrm{ml}$ oraz żel lub maść $0,02 \%$ podawane raz dziennie (odpowiedź mSWAT odpowiednio 46,9\% vs $46,2 \%$ ) (EBM 2) i karmustyna - maść 20-40\% lub roztwór $10 \mathrm{mg} / 60 \mathrm{ml}$ 95\% alkoholu raz dziennie. W MF IA-IIA można stosować fototerapię (EBM 2). Jeśli zmiany skórne mają charakter rumieniowy, można wdrożyć UVB311 (odstępuje się od UVB o szerokim spektrum), jeśli rumieniowo-naciekowy, zaleca się PUVA. Terapia PUVA: 8-metoksypsoralen + UVA, powinna być stosowana 2-3 razy w tygodniu do ustąpienia zmian skórnych (3-4 miesiące, gdy osiągnie się remisję, następnie z mniejszą częstością jeszcze 2-3 miesiące). Całkowita remisja (complete remission - CR) jest osiągana u 58-83\% pacjentów, częściowa remisja (partial remission - PR) w 95\% przypadków. Czas trwania remisji to średnio 43 miesiące. Rekomendacje EORTC z 2017 r. sugerują prowadzenie terapii analogicznie do tej w łuszczycy [5-8].

Rzadziej wykorzystywaną, ale również zalecaną metodą leczenia światłem MF jest promieniowanie UVA1. Mechanizm działania tego promieniowania wiąże się ze stymulacją wczesnej fazy apoptozy limfocytów i proliferujących mastocytów w mechanizmach odmiennych niż w przypadku UVB czy PUVA. Promieniowanie UVA1 zwiększa wytwarzanie anionów ponadtlenkowych oraz tlenu syngletowego, który stymuluje depolaryzację błony mitochondrialnej oraz aktywację apoptozy limfocytów T. Wykazano także, że UVA1 hamuje syntezę czynnika martwicy nowotworów $\alpha$ (tumor necrosis factor $\alpha-$ TNF- $\alpha$ ), interleukiny 12 (IL-12), interferonu $\gamma$ (IFN- $\gamma$ ) i cząsteczki adhezji międzykomórkowej 1 (intercellular adhesion molecule 1 - ICAM-1) oraz zmniejsza stężenie IL-6 i IL-8. Ostatnie badania wskazują ponadto, że promieniowanie UVA1 hamuje aktywność kalcyneuryny in vivo i in vitro i wykorzystuje tę samą ścieżkę sygnałową w skórze co inhibitory kalcyneuryny. W leczeniu MF, niezależnie od fazy choroby, zaleca się codzienne dawki średnie $40-80 \mathrm{~J} / \mathrm{cm}^{2}$ oraz wysokie 80-130 J/ cm² w ilości 10-35 na kurs [24-26]. Skuteczność światłoterapii PUVA lub UVA1 można zwiększyć, dodając retinoidy (acytretyna, izotretynoina), lub reksynoidy - beksaroten $300 \mathrm{mg} / \mathrm{m}^{2}$ p.c. p.o. lub IFN- $\alpha$. Połączenie PUVA z IFN- $\alpha$ lub acytretyny z IFN- $\alpha$ daje taką samą odpowiedź całkowitą (odpowiednio 90,5\% vs 90\%), ale remisję całkowitą osiągano częściej w pierwszym przypadku (70\% vs $38 \%$ ). Nie mają również przewagi inne retinoidy nad 
tin. For that reason, the combination is only recommended when there are contraindications to PUVA combined with IFN- $\alpha$. The superiority of the PUVA and bexarotene combination to PUVA alone has not been demonstrated (EORTC clinical trial ended prematurely because of low recruitment). Bexarotene can be used in monotherapy. It is recommended in patients who are refractory to at least one systemic therapy, and its rate of response is $45 \%$ (EBM 2). Similarly, IFN- $\alpha$ can be used from 3 MU three times a week with gradual dose escalation to max. $18 \mathrm{MU}$ (response is achieved in $0-80 \%$ of patients without dose correlation, EBM 2). Aside from teratogenicity, the most common adverse effects associated with bexarotene include hyperlipidaemia and central hypothyroidism, while IFN- $\alpha$ may induce adverse effects including flu-like symptoms, leucopaenia, thrombocytopaenia, elevated transaminase levels, depression and cardiac dysrhythmia. In the course of therapy, after improvement is noted, the dose can be reduced to 1.5 MU 2-3 times a week. Both drugs can be used in monotherapy, with initial response noted within 2-4 months. If PUVA is contraindicated, TSEB may be considered (CR: $60-90 \%$ of patients at T2-T4; 5-year relapse-free survival in IB-III: 10-25\%) (EBM 2). The mean response time is 5.2 months (83469 days). It is important to note that medical centres in Denmark and in the USA attempt to use lower doses of TSEB (10-12 Gy over 2-3 weeks) in order to be able to repeat therapy in relapses. There are no data comparing irradiation treatments with different doses of TSEB (EBM 2). Radiotherapy should be considered in patients with MF stage IIB (EBM 4). The dose recommended in solitary MF lesions is 20-24 Gy, though $35 \mathrm{~Gy}$ has also been used. In palliative therapy $2 \times 4$ Gy may be administered [5-8].

The majority $(80 \%)$ of relapses occur during the first year after irradiation, and nearly all - during the two-year period after the completion of treatment. In solitary and limited skin lesions, the 10 -year overall survival (OS) rate reaches $100 \%$, and 10 -year recurrence-free survival is observed in $80 \%$ of patients.

In a proportion of patients the treatment may be stopped after disease remission until relapse. Continuous maintenance therapy is required in some cases (minimum stage IB), for example with topical glucocorticosteroids, low doses of MTX, bexarotene and/or IFN- $\alpha$ at gradually decreasing doses or alternatively phototherapy once or twice a week, once a week, etc. Second-line therapy may include MTX administered orally (in three divided doses every 12 hours once a week) or intramuscularly (at the recommended dose of 5-25 mg a week, less commonly at higher doses of up to $75 \mathrm{mg}$ a week; lower doses may be used to sustain the remission) (EBM 3). The drug can be combined with glucocor- acytretyną w połączeniu z IFN- $\alpha$. Z tego powodu połączenie to zaleca się tylko, gdy są przeciwwskazania do PUVA z IFN- $\alpha$. Nie udało się udowodnić przewagi połączenia PUVA z beksarotenem nad PUVA (badanie kliniczne EORTC skończyło się przedwcześnie ze względu na małą rekrutację). Beksaroten można stosować w monoterapii - zalecany jest u pacjentów opornych na minimum jedną terapię systemową, odpowiedź wynosi 45\% (EBM 2). Podobnie IFN- $\alpha$, począwszy od 3 MU 3 razy w tygodniu, ze stopniową eskalacją dawki maks. do $18 \mathrm{MU}$ (odpowiedź osiąga 0-80\% pacjentów - bez korelacji ze stosowaną dawką, EBM 2). Działania niepożądane beksarotenu to, oprócz teratogenności, najczęściej hiperlipidemia i ośrodkowa niedoczynność tarczycy, a IFN- $\alpha-$ m.in. objawy paragrypowe, leukopenia, trombocytopenia, wzrost stężenia transaminaz, depresja, zaburzenia rytmu serca. Z czasem, po uzyskaniu poprawy, dawkę można zmniejszyć do 2-3 razy 1,5 MU tygodniowo. Powyższe leki można stosować w monoterapii; pierwsza odpowiedź występuje po 2-4 miesiącach. Jeżeli metoda PUVA jest przeciwwskazana, należy rozważyć terapię TSEB (CR 60-90\% pacjentów w T2-T4; 5-letnie przeżycie wolne od nawrotu w IB-III: 10-25\%) (EBM 2). Średni czas odpowiedzi wynosi 5,2 miesiąca (83-469 dni). Warto zauważyć, że ośrodki w Danii i USA podejmują próby wdrożenia niższych dawek TSEB (10-12 Gy w ciągu 2-3 tygodni), co umożliwia powtórzenie terapii w przypadku nawrotu. Nie ma danych porównujących naświetlania różnymi dawkami TSEB (EBM 2). W MF IIB należy rozważyć radioterapię (EBM 4). Dawka zalecana dla pojedynczych zmian MF wynosi 20-24 Gy, choć stosowano również 35 Gy. Paliatywnie można zastosować również 2 × 4 Gy [5-8].

Większość (80\%) nawrotów obserwuje się w pierwszym roku po napromienianiu, prawie wszystkie w ciągu 2 lat po zakończeniu leczenia. W przypadku zmian skórnych pojedynczych i ograniczonych 10-letnie przeżycie całkowite (overall survival - OS) wynosi $100 \%$, a 10-letni okres wolny od wznowy stwierdza się u $80 \%$ chorych.

U części pacjentów po uzyskaniu remisji można odstąpić od leczenia do czasu nawrotu, u niektórych chorych (min. Ib) konieczne jest stosowanie ciągłego leczenia podtrzymującego (np. terapia glikokortykosteroidami miejscowo, małymi dawkami MTX, beksarotenem i/lub IFN- $\alpha$ w stopniowo zmniejszanej dawce, ewentualnie fototerapia 1-2 razy w tygodniu, raz w tygodniu itd.). W leczeniu drugiej linii można zastosować MTX doustnie (w 3 dawkach podzielonych co 12 godzin raz w tygodniu) lub domięśniowo (w zalecanej dawce 5-25 mg tygodniowo, rzadziej w dawkach wyższych - do 75 mg tygodniowo; w celu podtrzymania remisji można stosować dawki niższe) (EBM 3). Lek ten można łączyć z glikokortykosteroidami, PUVA 
ticosteroids, PUVA and IFN- $\alpha$. If the lymph nodes and/or internal organs are involved, the response criteria and monitoring of the disease course are the same as in other cancers arising from mature lymphocytes. Some advanced MF cases may be treated with palliative low-dose total body irradiation with high-energy X-ray photons. Since chemotherapy does not prolong survival in MF stages IIB-IVB, the recommended therapeutic option is treatment provided within the framework of clinical trials prior to the initiation of systemic chemotherapy or bexarotene, IFN- $\alpha$ or denileukin diftitox (Ontak) 9 or $18 \mu \mathrm{g} / \mathrm{kg} \mathrm{BW} /$ day for 5 consecutive days every 3 weeks ( 8 cycles) [phase III clinical trial: total objective response rate (ORR) 30\%, 10\% CR; mean survival: 6-9 months, from 2.7 to 46.1 months] or histone deacetylase inhibitors (HDACi) approved by the U.S. Food and Drug Administration (FDA): vorinostat (phase II clinical trial: ORR $27.9 \%$, reduction of pruritus in $50 \%$ of patients, time to progression 4.9 months) and depsipeptide $\left(14 \mathrm{mg} / \mathrm{m}^{2}\right.$ BSA on days 1, 8 and 15, in cycles every 28 days; ORR 35\%, mean response time: 13.7 months). Panobinostat treatment (20 mg, 3 times a week) administered to patients after at least two systemic therapies has shown a reduction in the mSWAT score in $74.1 \%$ of subjects, with the ORR of $17.3 \%$ (phase IIb clinical trial) [5-8].

The efficacy of brentuximab vedotin demonstrated in phase II and III trials has been evaluated in MF/ SS as 70\%, at various degrees of CD30 expression on cancer cells (also when $<5 \%$ ). However, an adverse effect limiting the use of the drug on a chronic basis is peripheral neuropathy. Others include neutropaenia, fatigue, nausea and alopecia. At the stage of erythroderma with peripheral blood involvement, minimum stage $\mathrm{B} 1, \mathrm{OR}>50 \%$, patients can be treated with alemtuzumab (anti-CD52) 3 times a week at $30 \mathrm{mg}$ i.v. Since the dose predisposes patients to the development of opportunistic infections, lower doses (15 mg BSA s.c. every other day, or even $10 \mathrm{mg}$ ) are considered. A drug approved in Japan for the treatment of CTLC is mogamulizumab. In a phase III trial in CCR4+ CTCL patients, the response rate was 38\% [5-8].

Another therapeutic modality which may be considered in patients with erythroderma is extracorporeal photopheresis (ECP) - in combination with retinoids, IFN- $\alpha$, PUVA and other medications, though ECP seems beneficial primarily in the Sézary syndrome. Patients with slowly progressing disease may begin chemotherapy (last choice) with chlorambucil p.o. at a dose of $4 \mathrm{mg} /$ day or etoposide at $50 \mathrm{mg} /$ day. In patients with rapid disease progression monochemotherapy should preferably start with gemcitabine or liposomal doxorubicin. Pegylated liposomal i IFN- $\alpha$. W przypadku zajęcia węzłów chłonnych i/lub narządów wewnętrznych kryteria odpowiedzi i monitorowanie przebiegu choroby nie odbiegają od typowych dla innych nowotworów z dojrzałych limfocytów. W niektórych przypadkach zaawansowanych postaci MF można wdrożyć paliatywne napromienianie całego ciała wiązką wysokoenergetycznych fotonów X w małych dawkach. Zastosowanie chemioterapii w MF IIB-IVB nie przyczynia się do przedłużenia czasu przeżycia, dlatego też rekomendowaną opcją jest próba leczenia w ramach badań klinicznych przed wdrożeniem systemowej chemioterapii lub beksaroten, IFN- $\alpha$ albo denileukin diftitoks (Ontak) w dawce 9 lub $18 \mu \mathrm{g} / \mathrm{kg}$ m.c./dobę przez 5 kolejnych dni co 3 tygodnie (8 cykli) [badanie kliniczne III fazy: całkowity współczynnik odpowiedzi (objective response rate - ORR) 30\%, 10\% CR; średni czas przeżycia 6-9 miesięcy: od 2,7 do 46,1 miesiąca] lub inhibitory deacetylazy histonowej (histone deacetylase inhibitors - HDACi) zatwierdzone przez amerykańską Agencję ds. Żywności i Leków (Food and Drug Administration - FDA): worinostat (badania kliniczne fazy II: ORR 27,9\%, redukcja świądu u 50\% pacjentów, czas do progresji 4,9 miesiąca) i depsipeptyd (14 mg/ m² p.c. w dniach 1., 8. i 15., w cyklach co 28 dni; ORR 35\%, średni czas odpowiedzi na leczenie: 13,7 miesiąca). Leczenie panabinostatem (20 mg 3 razy w tygodniu) pacjentów poddanych minimum dwóm terapiom systemowym wykazało zmniejszenie mSWAT u 74,1\%, przy ORR 17,3\% (badanie kliniczne fazy IIb) [5-8].

W badaniu II i III fazy skuteczność leku brentuksymab wedotin oceniono w MF/SS na 70\%, przy różnym stopniu ekspresji CD30 na komórkach nowotworowych (także < 5\%). Działaniem niepożądanym ograniczającym przewlekłe stosowanie jest neuropatia obwodowa. Do innych należą neutropenia, zmęczenie, nudności i łysienie. Lekiem dla pacjentów w stadium erytrodermii z zajęciem krwi obwodowej minimum B1 o OR > 50\% jest alemtuzumab (antyCD52) $30 \mathrm{mg}$ i.v. 3 razy w tygodniu. Ponieważ dawka ta sprzyja rozwojowi infekcji oportunistycznych, rozważane jest stosowanie dawek mniejszych: $15 \mathrm{mg}$ s.c. co 2 dni lub nawet $10 \mathrm{mg}$. Zatwierdzony do leczenia CTCL w Japonii jest także mogamulizumab. W badaniu III fazy u pacjentów CCR4+ CTCL uzyskano odpowiedź w 38\% [5-8].

U pacjentów z erytrodermią można rozważyć fotoferezę pozaustrojową (extracorporeal photopheresis - ECP) w połączeniu $z$ retinoidami, IFN- $\alpha$, PUVA i innymi, choć ECP wydaje się zasadna głównie w zespole Sezary'ego. U chorych z wolną progresją choroby chemioterapię (ostatni wybór) można rozpoczać od chlorambucylu p.o. w dawce $4 \mathrm{mg} /$ dobę lub etopozydu w dawce $50 \mathrm{mg} /$ dobę. U chorych z gwałtowną progresją zaleca się rozpoczynanie monochemioterapii od gemcytabiny lub liposomalnej doksorubicyny. Forma pegylowana liposomalnej 
doxorubicin (PLD) at a dose of $20 \mathrm{mg} / \mathrm{m}^{2}$ BSA i.v. once monthly results in CR + PR in $88 \%$ of patients (EBM 4). Since the combination of gemcitabine or liposomal doxorubicin with bexarotene does not provide any therapeutic advantage over the chemotherapeutic agent alone in terms of treatment response, but increases toxicity, it is not recommended. Polychemotherapy should be used in patients refractory to previous treatment (stages IVA-IVB) who require rapid tumour mass reduction. Polychemotherapy regimens (EBM 4) such as $\mathrm{CHOP}$ (cyclophosphamide, hydroxydaunorubicin, oncovin, prednisone or prednisolone), EPOCH (etoposide, vincristine, doxorubicin, cyclophosphamide, prednisone), ESHAP (etoposide, cisplatin, high-dose cytosine arabinoside, methylprednisolone) or cladribine/fludarabine in combination with cyclophosphamide (CC/FC) produce a short-term response (often persisting for just several weeks). Oral antibiotic prophylaxis is indicated in cases involving tumour disintegration. Ulcers should be treated topically with antiseptic agents (e.g. octenidine dihydrochloride). In young patients with MF stages III-IV and in good general condition, but with a history of unsuccessful treatment, allogeneic stem cell transplantation (allo-SCT) should be considered prior to the initiation of cytostatic treatment, with a response rate of 44-46\% (EBM 3) [5-8, 11, 21, 27-37] (Tab. 7).

The prognosis in patients with MF depends on the stage of the disease. $97-98 \%$ of patients with MF stage IA achieve 10-year survival. When the disease involves more than $10 \%$ of the skin surface, the 10 year survival rate is approximately $83 \%$. In MF stage IIB, it falls to $42 \%$, and in MF stage IV - to $20 \%$.

\section{Lymphomatoid papulosis}

Lymphomatoid papulosis (LyP) is a chronic disease which presents with mildly exfoliating and later ulcerating papules located on the skin of the trunk and/or extremities. The lesions resolve and recur every 3-12 weeks. Lymphomatoid papulosis mainly affects adults, with a slight predominance of the male sex, and the median age at diagnosis is 45 years [37, 38]. Lymphomatoid papulosis can be divided into five histopathological types [16, 19]:

- A - minor infiltrates of large CD30+ T lymphocytes surrounded by histiocytes, small lymphocytes, granulocytes and eosinophils,

- B - epidermotropism with infiltration consisting of small atypical lymphocytes with hyperchromatic cerebriform nuclei, similar in appearance to MF-typical cells, accompanied by the presence of the same antigens as in C-ALCL,

- C - monomorphic infiltrates containing large CD30+ T lymphocytes, doksorubicyny (PLD) w dawce $20 \mathrm{mg} / \mathrm{m}^{2}$ p.c. i.v. raz w miesiącu umożliwia osiągnięcie CR + PR u $88 \%$ chorych (EBM 4). Łączenie gemcytabiny lub liposomalnej doksorubicyny z beksarotenem nie prowadzi do uzyskania wyższej odpowiedzi terapeutycznej niż w przypadku zastosowania chemioterapeutyku, przy jednoczesnym wzroście toksyczności - nie jest zalecane. Polichemioterapia powinna być stosowana u chorych opornych na wcześniejsze leczenie w stadium IVA-IVB, u których konieczna jest szybka redukcja masy guza. Zastosowanie polichemioterapii (EBM 4), np. schematów CHOP (cyklofosfamid, hydroksydaunorubicyna, winkrystyna, prednizon lub prednizolon), EPOCH (etopozyd, winkrystyna, doksorubicyna, cyklofosfamid, prednizon), ESHAP (etopozyd, cisplatyna, duże dawki arabinozydu cytozyny, metyloprednizolon) czy kladrybiny lub fludarabiny w połączeniu z cyklofosfamidem (CC/FC), pozwala na uzyskanie krótkotrwałej odpowiedzi (często tylko kilka tygodni). W przypadku rozpadu guzów wskazane jest stosowanie doustnej profilaktyki antybiotykowej. Miejscowo na owrzodzenia zaleca się używanie środków antyseptycznych (np. dichlorowodorku oktenidyny). U młodych pacjentów z MF IIB-IV, w dobrym stanie ogólnym, u których nie uzyskano efektu po terapii, przed rozpoczęciem leczenia cytostatycznego należy rozważyć allogeniczne przeszczepienie komórek macierzystych (allogeneic stem cell transplantation - allo-SCT), odpowiedź na leczenie wynosi 44-46\% (EBM 3) [5-8, 11, 21, 27-37] (tab. 7).

Rokowanie u chorych z MF zależy od stopnia zaawansowania. W MF IA 10 lat przeżywa 97-98\% chorych. Gdy zmiany tego typu zajmują więcej niż $10 \%$ powierzchni skóry, 10-letnie przeżycie wynosi ok. $83 \%$, w IIB - $42 \%$, a w MF IV - $20 \%$.

\section{Lymphomatoid papulosis}

Lymphomatoid papulosis (LyP) jest przewlekłą chorobą przebiegającą z obecnością grudek z niewielkim złuszczaniem na skórze tułowia i/lub kończyn, z czasem wrzodziejących, które zanikają i nawracają co ok. 3-12 tygodni. Chorują głównie dorośli, nieznacznie częściej mężczyźni, a mediana wieku wynosi 45 lat $[37,38]$. Znanych jest 5 typów histopatologicznych LyP $[16,19]$ :

- A - drobne nacieki złożone z dużych limfocytów T CD30+, otoczone przez histiocyty, małe limfocyty, granulocyty i eozynofile,

- B - epidermotropizm z naciekiem z małych atypowych limfocytów o pofałdowanym jądrze typu cerebriformis, podobnych do komórek w MF, z obecnością takich antygenów jak w C-ALCL,

- C - monomorficzne nacieki z dużych limfocytów T $\mathrm{CD} 30+$ 
- D - infiltrate similar to those found in aggressive epidermotropic lymphoma arising from CD8+ cytotoxic cells or/and resembling pagetoid reticulosis (CD8+ CD30+, occasionally CD4+ CD56+),

- E - angioinvasive and angiodestructve infiltrate of atypical small and-medium sized CD30+ and often CD8+ lymphocytes,

- F - with folliculotropic lymphocytic infiltrate; the subtype is occasionally classified as subtypes A, B or $\mathrm{C}$ with pronounced folliculotropism; the prognosis in LyP F is not worse than in subtypes A, B or C.

Patients presenting with solitary skin lesions with a tendency to resolve spontaneously require no treatment (watch-and-wait approach). In others the disease is controlled through the use of small doses of metotrexate (MTX) (5-20 mg once a week, with folic acid supplementation at a dose of 5-10 mg once a week on a MTX-free day). Another available therapeutic modality is PUVA which can be combined with IFN- $\alpha$, retinoids or bexarotene. Persistent solitary lesions of more than $2 \mathrm{~cm}$ in diameter may be removed surgically or treated with radiotherapy (as in MF). Although there is no cure, the 10-year survival rate is achieved in approximately $100 \%$ of all patients. LyP coexists with lymphoproliferative disorders, usually ALCL, MF, Hodgkin lymphoma (HL) or non-Hodgkin lymphoma (nHL), in 30-50\% of patients. Consequently, even untreated patients require constant close monitoring (Tab. 8). There are no established recommendations as to the frequency of performing imaging studies and blood tests. It should be adjusted to the general condition of the patient and subjective signs and symptoms [5-8, 37, 38].

\section{Primary cutaneous anaplastic large cell lymphoma}

Primary cutaneous anaplastic large cell lymphoma (C-ALCL) occurs primarily in male adults. The clinical presentation of the disease includes solitary (80\%) or multiple $(20 \%)$ tumours with diameters in the range of 1-10 cm. Progression with local lymph node involvement is noted in $10 \%$ of patients. In such cases, skin involvement secondary to the sys-
- D - naciek jak w agresywnym chłoniaku epidermotropowym z komórek cytotoksycznych CD8+i/lub przypominający siatkowicę pagetoidalną (CD8+ CD30+, czasem CD4+CD56+),

- E - z angiocentrycznym $\mathrm{i}$ angiodestrukcyjnym naciekiem atypowych, małych i średniej wielkości limfocytów CD30+ i często CD8+,

- F - z limfocytarnym naciekiem okołomieszkowym (folikulotropowym); czasami podtyp jest klasyfikowany do podtypów A, B, C z nasilonym folikulotropizmem; LyP F nie rokuje gorzej niż odmiany A, B lub C.

Chorzy, u których zmiany skórne są pojedyncze i mają tendencję do ustępowania, nie wymagają leczenia (postawa wyczekująca - watch and wait). U pozostałych kontrolę choroby uzyskuje się poprzez stosowanie metotreksatu (MTX) (5-20 mg raz w tygodniu; z suplementacją kwasem foliowym w dawce 5-10 mg raz $\mathrm{w}$ tygodniu $\mathrm{w}$ dniu bez MTX). Inną metodą terapii jest PUVA, którą można łączyć z IFN- $\alpha$, retinoidami lub beksarotenem. Uporczywe pojedyncze zmiany o średnicy powyżej $2 \mathrm{~cm}$ można usunąć chirurgicznie lub poddać radioterapii (jak w MF). Choroba jest nieuleczalna, ale przeżycie 10-letnie osiąga prawie 100\% pacjentów. U 30-50\% chorych współistnieją inne rozrosty limfoproliferacyjne, najczęściej o typie ALCL, MF, chłoniak Hodgkina (Hodgkin lymphoma - HL) lub non-Hodgkin lymphoma (nHL). Z tego powodu pacjent, nawet gdy nie jest leczony, wymaga stałej, wnikliwej obserwacji (tab. 8). Nie ma ustalonej częstości wykonywania badań obrazowych i badań krwi. Decyduje o tym stan chorego i ewentualne objawy subiektywne $[5-8,37,38]$.

\section{Pierwotny skórny chłoniak anaplastyczny z dużych komórek}

Pierwotny skórny chłoniak anaplastyczny z dużych komórek (primary cutaneous anaplastic large cell lymphoma - C-ALCL) występuje głównie u dorosłych, przeważnie mężczyzn. Klinicznie objawia się pojedynczymi (80\%) lub mnogimi (20\%) guzami o średnicy $1-10 \mathrm{~cm}$. U ok. $10 \%$ chorych dochodzi do progresji z zajęciem oko-

Table 8. Treatment of lymphomatoid papulosis

Tabela 8. Leczenie lymphomatoid papulosis

First-line treatment/Pierwsza linia leczenia:

- expectant policy (watch and wait)/postawa wyczekująca (watch and wait)

Second-line treatment - for multiple lesions or in exposed sites and/or with persistent pruritus/Druga linia leczenia - w przypadku zmian licznych lub w miejscach eksponowanych i/lub z uporczywym świądem:

- MTX (5-20 mg once a week, with folic acid supplementation at 5- 10 mg once a week on a MTX-free day)/MTX (5-20 mg raz w tygodniu; z suplementacją kwasem foliowym w dawce 5-10 mg raz w tygodniu w dniu bez MTX)

- PUVA alone or with IFN- $\alpha$, retinoids or bexarotene (doses as in MF)/PUVA w monoterapii lub z IFN- $\alpha$, retinoidami lub beksarotenem (dawki jak w MF)

- radiotherapy or surgical excision for persistent solitary lesions (as in MF)/radioterapia lub usunięcie chirurgiczne w przypadku uporczywych pojedynczych zmian (jak w MF) 
Table 9. Treatment of primary cutaneous anaplastic CD30+ lymphoma

Tabela 9. Leczenie pierwotnie skórnego chłoniaka anaplastycznego CD30+

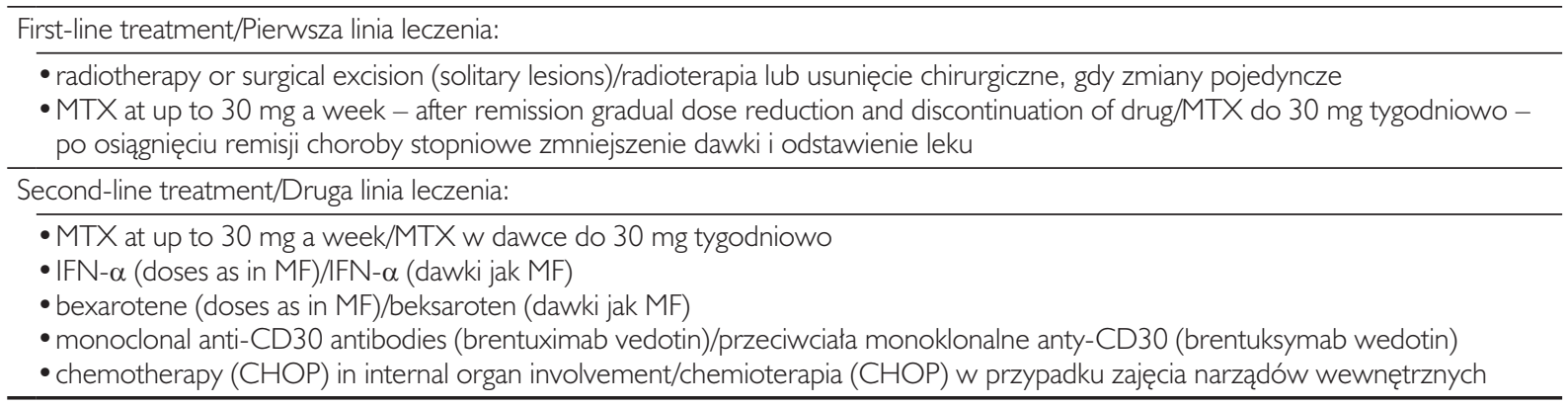

temic form of ALCL, HL or MF CD30+ should be ruled out. Histopathologically, C-ALCL demonstrates a diffuse infiltrate of CD4+ lymphocytes which have lost the expression of one or more antigens specific to T lymphocytes (CD2, CD3, CD5). To diagnose C-ALCL, over $75 \%$ of cells must express the CD30 antigen. Cancer cells express the cutaneous lymphocyte antigen (CLA) and typically lack the epithelial membrane antigen (EMA) and anaplastic lymphoma kinase (ALK). Treatment is based on MTX at a weekly dose of $30 \mathrm{mg}$ (in three doses, similarly to MF). After remission is achieved, the treatment may be gradually withdrawn, usually with no relapses. Solitary tumours can be surgically removed or treated with radiotherapy (CR 95\%). Spontaneous or partial tumour remissions are seen in about $44 \%$ of cases between 1 week and 6 months from the onset. In the rare cases of secondary involvement of internal organs, chemotherapy (CHOP) is recommended. IFN- $\alpha$, bexarotene and anti-CD30 monoclonal antibodies (brentuximab vedotin) may also be considered. The prognosis is good, with over $90 \%$ of patients achieving 10-year survival (Tab. 9) [5-8, 15, 19, 37, 38].

\section{Primary cutaneous CD4+ small/medium T-cell lymphoma}

Primary cutaneous CD4+ small/medium T-cell lymphoma (CSMTCL) presents with solitary plaques or tumours located primarily on the upper half of the body. CSMTCL may only be diagnosed when MF-typical lesions are absent (also in history). Histopathological examination of the skin reveals a dense, diffuse infiltrate containing small and medium-sized T lymphocytes with CD3+, CD4+, CD8- and CD30- phenotypes, and a significant proportion of B lymphocytes and histiocytes. Pleomorphic large T lymphocytes should not constitute more than $30 \%$ of cells. Cancerous infiltration usually penetrates into the deeper layers of the skin or even the subcutaneous tissue, with sporadically identified focal epidermotropism. Solitary licznych węzłów chłonnych - wówczas należy wykluczyć, że zajęcie skóry jest wtórne do postaci układowej ALCL, HL lub MF CD30+. W badaniu histopatologicznym skóry stwierdza się rozlany naciek z limfocytów CD4+, które utraciły ekspresję jednego lub kilku antygenów typowych dla limfocytów T, tj. CD2, CD3, CD5. Do rozpoznania konieczne jest ponad 75\% komórek z ekspresją antygenu CD30. Komórki nowotworowe cechują się ekspresją skórnego antygenu limfocytarnego (cutaneous lymphocyte antigen - CLA), przy braku nabłonkowego antygenu błonowego (epithelial membrane antigen - EMA) i kinazy chłoniaka anaplastycznego (anaplastic lymphoma kinase - ALK). Leczenie stanowi MTX w dawce do $30 \mathrm{mg}$ tygodniowo (w 3 dawkach jak w MF). Po osiągnięciu remisji leczenie można stopniowo odstawiać i zwykle nie obserwuje się nawrotów. Pojedyncze guzy można leczyć poprzez wycięcie chirurgiczne lub radioterapię (CR 95\%). W ok. 44\% obserwuje się samoistne całkowite lub częściowe remisje guzów (po 1 tygodniu do 6 miesięcy od wystąpienia zmiany). W rzadkich przypadkach wtórnego zajęcia narządów wewnętrznych, zaleca się chemioterapię (CHOP). Można rozważyć IFN- $\alpha$, beksaroten i przeciwciała monoklonalne anty-CD30 (brentuksymab wedotin). Rokowanie jest dobre - ponad $90 \%$ chorych osiąga 10-letnie przeżycie (tab. 9) [5-8, 15, 19, 37, 38].

\section{Pierwotny skórny chłoniak z małych lub średnich komórek T CD4+}

Pierwotny skórny chłoniak z małych lub średnich komórek T CD4+ (primary cutaneous CD4+ small/medium T-cell lymphoma - CSMTCL) objawia się jako pojedyncze nacieki lub guzy, zwykle na górnej części ciała. Rozpoznanie można ustalić tylko przy braku (także w wywiadzie) obecności zmian typowych dla MF. W badaniu histopatologicznym skóry stwierdza się gęsty, rozlany naciek, złożony z małych i średnich limfocytów T o fenotypie CD3+CD4+CD8-CD30-, przy znaczącym udziale limfocytów B i histiocytów. Pleomorficzne, duże limfocyty T powinny stanowić mniej niż 30\% komórek. Naciek nowotworowy wnika zwykle do głębszych warstw skóry, a nawet tkanki podskórnej, czasami ogniskowo można stwierdzić epidermotropizm. 
Table 10. Diagnostic criteria of Sézary syndrome

Tabela 10. Kryteria diagnostyczne zespołu Sézary'ego

\begin{tabular}{l}
\hline Erythroderma with peripheral lymphadenopathy/Erytrodermia z limfadenopatią obwodową \\
\hline Detection of clonal T lymphocyte populations in the skin and peripheral blood by PCR gene rearrangement analysis/Wykazanie \\
metodą rearanżacji genów PCR populacji klonalnych limfocytów T w skórze i we krwi obwodowej \\
\hline Absolute Sézary cell count of at least I000/ml in peripheral blood/Obecność we krwi obwodowej komórek Sézary'ego \\
w bezwzględnej liczbie I000/ml \\
\hline Alternatively, increased CD4/CD8 ratio of > I0 or increased count of CD4+ T lymphocytes with phenotype CD4+/CD7- > 40\% \\
or CD4+/CD26->30\%/Alternatywnie, zwiększenie stosunku CD4/CD8 więcej niż I0 lub wzrost liczby limfocytów T CD4+ \\
z fenotypem CD4+/CD7-> $>$ 40\%, lub CD4+/CD26->30\%
\end{tabular}

Table II. Treatment of Sézary syndrome (drug dosage as in advanced MF stages - see table 7)

Tabela II. Leczenie zespołu Sézary'ego (dawkowanie leków - jak w zaawansowanych stadiach MF - patrz tabela 7)

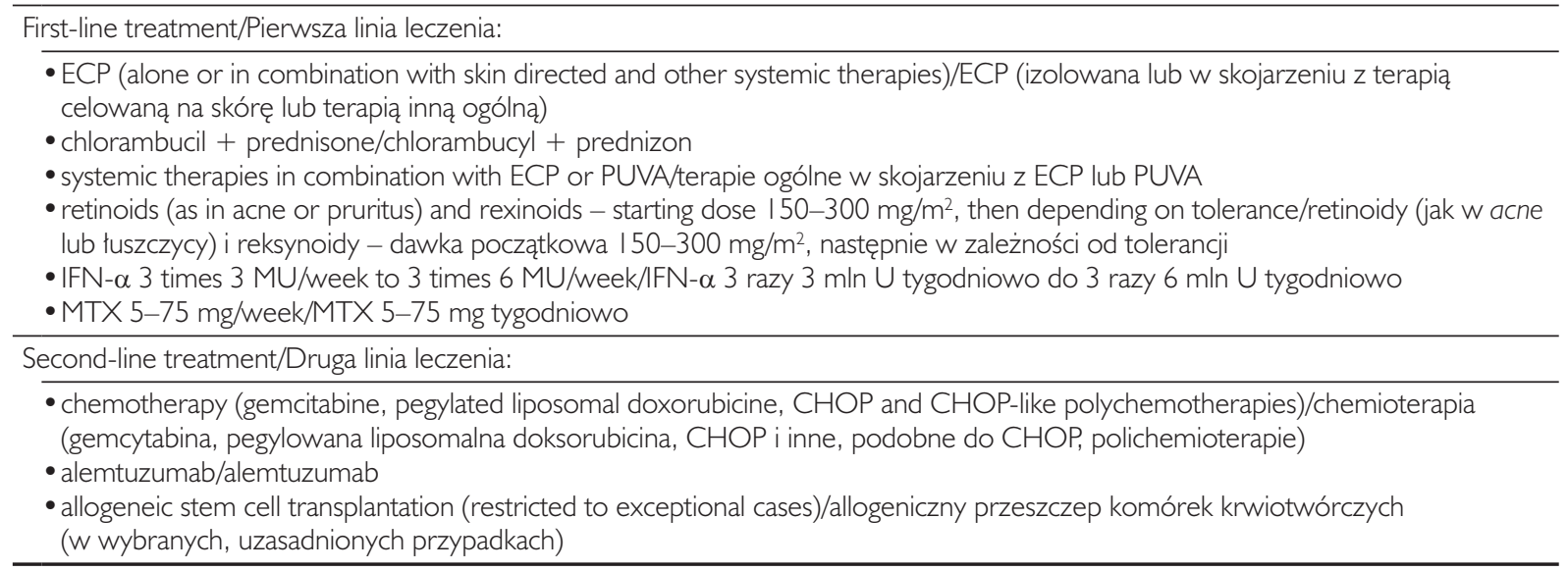

CHOP - cyclophosphamide + hydroxydaunomycin (doxorubicin) + Oncovin (vincristine) + prednisone; ECP - extracorporeal photopheresis; MTX - methotrexate; IFN - interferon; RT - localized radiotherapy; TSEB - total skin electron beam/CHOP - cyklofosfamid + hydroksydaunomycyna (doksorubicyna) + Oncovin (winkrystyna) + prednizon, ECP - fotoforeza pozaustrojowa, MTX - metotrexat, IFN - interferon, RT - miejscowa radioterapia, TSEB - napromieniowanie elektronami całego ciała.

skin lesions may be treated surgically or with radiotherapy. Cyclophosphamide or IFN- $\alpha$ are used in cases with generalized lesions. The prognosis is good, with $60-80 \%$ of all patients achieving 5-year survival [5-8, 14, 19].

\section{Sézary syndrome}

Sézary syndrome (SS) is a condition characterized by a triad of symptoms including erythroderma (which must be differentiated from MF III with a better prognosis), generalized lymphadenopathy, and atypical $\mathrm{T}$ lymphocytes with cerebriform nuclei in the skin, lymph nodes and peripheral blood. For the diagnosis of SS, at least one of the following criteria must be met: absolute Sézary cell count in peripheral blood of at least 1,000 cells $/ \mathrm{mm}^{3}$; abnormal antigens on the surface of $\mathrm{T}$ lymphocytes, i.e. increase in CD4+ population with a shift in the CD4+/CD8+ ratio to more than 10 and/or loss of one or all antigens typical of T lymphocytes (CD2, CD3, CD4, CD5); clonality of $\mathrm{T}$ lymphocytes in peripheral blood detected by molecular or cytogenetic methods (Tab. 10). The syndrome affects mainly adults (median age at diagnosis: 63 years), more often men than women. The initial eczema-like skin lesions are replaced by erythro-
W przypadku występowania pojedynczych zmian skórnych można zastosować wycięcie chirurgiczne lub radioterapię. Jeśli zmiany są uogólnione, stosuje się cyklofosfamid lub IFN- $\alpha$. Rokowanie jest dobre, 5-letnie przeżycie osiąga $60-80 \%$ chorych [5-8, 14, 19].

\section{Zespół Sézary’ego}

Zespół Sézary'ego (Sézary syndrome - SS) to współwystępowanie trzech objawów: erytrodermii (konieczne odróżnienie od MF III o lepszym rokowaniu), uogólnionej limfadenopatii oraz obecności atypowych limfocytów $\mathrm{T}$ o pofałdowanym jądrze (nucleus cerebriformis) w skórze, węzłach chłonnych i krwi obwodowej. Przy rozpoznaniu wymagane jest uwzględnienie przynajmniej jednego z następujących kryteriów: bezwzględna liczba komórek Sézary'ego minimum 1000/ $\mathrm{mm}^{3}$ we krwi obwodowej; obecność nieprawidłowych antygenów na powierzchni limfocytów T, tj. zwiększenie populacji limfocytów CD4+ z przesunięciem proporcji CD4+/CD8+ powyżej $10 \mathrm{i} /$ lub utrata jednego lub wszystkich antygenów typowych dla limfocytów T (CD2, CD3, CD4, CD5); wykazanie klonalności limfocytów T we krwi obwodowej za pomocą metod molekularnych lub cytogenetycznych (tab. 10). Zespół występuje głównie u dorosłych (me- 
derma with strong pruritus. Other symptoms of SS include alopecia, onychodystrophy, and palmar and plantar hyperkeratosis. Histopathological examination may produce findings similar to MF, but epidermotropism is less common. The treatment of choice is ECP, often combined with bexarotene or IFN- $\alpha$ (CR + PR 30-80\%, CR 14-25\%). Systemic treatment should start with IFN- $\alpha$, bexarotene, romidepsin and denileukin diftitox. The general recommendations concerning systemic chemotherapy in SS are similar to MF. Chlorambucil treatment may also be considered. Before chemotherapy is prescribed to younger patients, allo-HSCT should be considered (Tab. 11). The prognosis in SS is unfavourable. The median survival is 2-4 years, and death occurs mainly from infectious complications [5-8, 13, 14, 30, 31, 35].

\section{Primary cutaneous $\gamma \delta$ T-cell lymphoma}

Primary cutaneous $\gamma \delta$ T-cell lymphoma (PCGDTCL) is characterized by disseminated infiltrates and/or ulcerating papules and tumours located mainly on the extremities. The mucous membranes and internal organs are often involved, but the involvement of the lymph nodes, spleen or bone marrow is rare. Histopathological evaluation of the skin reveals infiltrates of cells with CD2+CD3+CD5CD7+/-CD56+bF1- $\gamma \delta+C D 4-C D 8-$ phenotype in the epidermis, dermis and/or subcutaneous tissue. There is no optimal therapy, and the most common treatment modality is chemotherapy (CHOP or others) in combination with radiotherapy. Young patients should be considered for allo-HSCT. The median survival is 15 months $[5-8,15,19]$.

\section{Primary cutaneous CD8+ aggressive epidermotropic cytotoxic T-cell lymphoma}

Primary cutaneous CD8+ aggressive epidermotropic cytotoxic T-cell lymphoma (AECTCL) manifests clinically with well-circumscribed or diffuse skin papules, nodules and tumours, often with central necrosis. Lymphomatous infiltrates may also be found in the lungs, testes, central nervous system (CNS) and oral mucosa. Histopathological evaluation shows epidermotropism of $\mathrm{T}$ lymphocytes: $\mathrm{CD} 3+\mathrm{CD} 8+-\mathrm{bF} 1+$ granzymeB+perforin+TIA-1+CD45RA+CD45RO-CD2-CD4-CD5-CD7+/-. AECTCL should be differentiated with indolent CD8+ lymphoid proliferation of the ear (which may include tumorous lesions localized in the nose) with histopathological features typical of aggressive lymphoma (CD3+CD4-CD8+TIA-1+granzymeB-CD30-) but a benign clinical course. There is no optimal therapy for AECTCL. The disease is usually treated with polychemotherapy (CHOP or others) in combination with radiotherapy. Young patients in a good general diana wieku: 63 lata), częściej u mężczyzn. Początkowo zmiany skórne przypominają wyprysk, następnie pojawia się erytrodermia $z$ silnym świądem. Inne objawy to łysienie, onychodystrofia, nadmierne rogowacenie skóry dłoni i stóp. Badanie histopatologiczne bywa analogiczne do obrazu MF, rzadziej występuje epidermotropizm. Leczeniem z wyboru jest ECP, często w połączeniu z beksarotenem lub IFN- $\alpha$ (CR + PR 30-80\%, CR 14-25\%). Zaleca się rozpoczynanie leczenia systemowego od IFN- $\alpha$, beksarotenu, romidepsyny i denileukinu diftitoksu. Zasady stosowania chemioterapii systemowej są podobne jak w MF. Można rozważyć leczenie chlorambucylem. U młodych chorych przed zastosowaniem chemioterapii warto rozważyć allo-HSCT (tab. 11). Rokowanie jest niepomyślne. Mediana przeżycia wynosi 2-4 lata, zgon następuje głównie wskutek powikłań infekcyjnych [5-8, 13, 14, 30, 31, 35].

\section{Pierwotny skórny chłoniak z komórek $\mathrm{T} \gamma \delta$}

$\mathrm{W}$ pierwotnym skórnym chłoniaku z komórek $\mathrm{T} \gamma \delta$ (primary cutaneous $\gamma \delta$ T-cell lymphoma - PCGD-TCL) rozsiane nacieki i/lub wrzodziejące grudki oraz guzy występują głównie na kończynach. Często zajęte są błony śluzowe i narządy wewnętrzne, ale rzadko węzły chłonne, śledziona lub szpik kostny. W badaniu histopatologicznym skóry stwierdza się nacieki z komórek w naskórku, skórze właściwej i/lub tkance podskórnej o fenotypie CD2+CD3+CD5-CD7+ /CD56+bF1- $\gamma \delta+C D 4-C D 8-$. Optymalne leczenie nie jest znane; najczęściej włączana jest chemioterapia (CHOP lub inne) w połączeniu z radioterapią. U młodych chorych należy rozważyć allo-HSCT. Mediana przeżycia wynosi 15 miesięcy [5-8, 15, 19].

\section{Pierwotny agresywny skórny chłoniak epidermotropowy z cytotoksycznych komórek T CD8+}

Pierwotny agresywny skórny chłoniak epidermotropowy z cytotoksycznych komórek T CD8+ (primary cutaneous CD8+ aggressive epidermotropic cytotoxic T-cell lymphoma - AECTCL) objawia się ograniczonymi lub rozsianymi grudkami, guzkami i guzami, często z centralną martwicą. Nacieki chłoniakowe obserwuje się też w płucach, jądrach, ośrodkowym układzie nerwowym (OUN), na śluzówkach jamy ustnej. W badaniu histopatologicznym stwierdza się epidermotropizm limfocytów T CD3+CD8+bF1+granzym B+perforyna+TIA-1+CD45RA+CD45RO-CD2-CD4-CD5-CD7+/Nowotwór AECTCL należy różnicować z limfoidalną proliferacją CD8+ ucha (możliwe są też zmiany guzowate w obrębie nosa) o cechach histopatologicznych typowych dla agresywnego chłoniaka (CD3+CD4CD8+TIA-1+granzym B-CD30-), ale o łagodnym przebiegu klinicznym. Optymalne leczenie AECTCL nie jest znane - najczęściej jest to polichemioterapia (CHOP lub inne) $\mathrm{w}$ połączeniu $\mathrm{z}$ radioterapią. $U$ młodych chorych 
condition should be considered for allo-HSCT. The median survival is 32 months $[5-8,15,19]$.

\section{Extranodal NK/T-cell lymphoma, nasal type}

Extranodal NK/T-cell lymphoma, nasal type (ENKTCL), typically involves the nasal cavity and throat. The skin is the second most common extranodular location of ENKTCL. Clinically, it is manifested with multiple infiltrates or tumours located on the skin of the trunk and extremities - or a solitary tumour in the nasopharynx which tends to destroy surrounding tissues. Accompanying symptoms include fever, fatigue, body weight loss and HPS. Histopathological examination reveals NK/T cell infiltrates within the dermis and in the subcutaneous tissue, occasionally with epidermotropism. Cancerous infiltrates may surround blood vessels, leading to their destruction and thus hindering immunophenotyping analysis. Involved field radiotherapy (IF-RT) is the treatment of choice in cases of limited disease (Ann Arbor stages I-II) combined with CNS prophylaxis in patients at higher risk of CNS involvement (nasal cavity, paranasal sinuses, orbit and testes). Cases of more advanced disease (Ann Arbor stages III-IV) and relapses are treated with radiotherapy combined with chemotherapy (CHOP regimen) or multidrug regimens comprising L-asparaginase and etoposide. In cases with lesions limited to the skin the median survival is 27 months, and in cases with extracutaneous lesions -5 months. The 5-year survival rate is below $25 \%$ [5-8, 15, 19].

Another CTCL variant (in ICD-O-3 classification), called primary cutaneous acral CD8+ T-cell lymphoma, has recently been described. Clinically, it is manifested with a painful, slowly growing cutaneous nodule, mainly affecting men at about 54 years of age. Histopathological findings include a dense infiltrate of medium-sized and large CD8+ cells, with focal TIA+granzyme+ and partial loss of CD3, CD5, CD7 in the skin, sparing the epidermis and revealing a thin grenz zone. The atypical lymphocytes are blast-like, with irregular nuclei and small nucleoli. Signet ring cells can also be present. There is are no signs of necrosis or angiodestruction. The cancer does not involve internal organs. The treatment method of choice is surgical excision [39].

\section{PRIMARY CUTANEOUS B-CELL LYMPHOMAS}

(TAB. 12)

The diagnosis is based on a combination of histopathological findings and clinical features (differentiation with systemic lymphomas producing analogous or similar histopathological characteristics is necessary). w dobrym stanie ogólnym należy rozważyć allo-HSCT. Mediana przeżycia wynosi 32 miesiące $[5-8,15,19]$.

\section{Pozawęzłowy chłoniak z komórek NK/T typu nosowego}

Pozawęzłowy chłoniak z komórek NK/T typu nosowego (extranodal NK/T-cell lymphoma, nasal type ENKTCL) zajmuje zwykle jamę nosową i gardło. Skóra jest drugą pod względem częstości występowania pozawęzłową lokalizacją ENKTCL. Klinicznie stwierdza się mnogie nacieki lub guzy na skórze tułowia i kończyn lub pojedynczy guz w jamie nosowo-gardłowej $\mathrm{z}$ tendencją do niszczenia otaczających tkanek. Objawy towarzyszące to: gorączka, osłabienie, utrata masy ciała, HPS. W badaniu histopatologicznym stwierdza się nacieki z komórek NK/T w skórze właściwej i tkance podskórnej, niekiedy z epidermotropizmem. Nacieki nowotworowe mogą otaczać naczynia krwionośne, co powoduje ich destrukcję utrudniającą immunofenotypowanie. Leczeniem z wyboru w przypadkach choroby ograniczonej (I-II wg skali Ann Arbor) jest miejscowa radioterapia (involved field radiotherapy - IF-RT) i profilaktyka zmian w OUN w razie lokalizacji sprzyjającej ich występowaniu (jama nosowa, zatoki przynosowe, oczodół, jądra). W przypadkach wyższego zaawansowania (III-IV wg skali Ann Arbor) oraz w okresie nawrotów stosuje się leczenie skojarzone radioterapią i chemioterapią CHOP lub za pomocą schematów wielolekowych zawierających L-asparaginazę albo etopozyd. Jeśli zmiany są ograniczone wyłącznie do skóry, mediana przeżycia wynosi 27 miesięcy; w razie zmian poza skórą 5 miesięcy. Odsetek chorych przeżywających 5 lat nie przekracza 25\% [5-8, 15, 19].

Ostatnio opisano kolejną odmianę CTCL (w klasyfikacji ICD-O-3) - pierwotnie skórny chłoniak akralny CD8+. Klinicznie stwierdza się bolesny, wolno rosnący guzek skórny występujący głównie u mężczyzn ok. 54 . roku życia. Histopatologicznie opisano gęsty naciek z komórek średniej i dużej wielkości CD8+ ogniskowo TIA+granzym+ z częściową utratą CD3, CD5, CD7 w skórze, oszczędzający naskórek, z obecnością cienkiej grenz zone. Atypowe limfocyty przypominają blasty z nieregularnym jądrem i małymi jąderkami. Mogą być obecne również komórki sygnetowate. Nie stwierdza się nekrozy i angiodestrukcji. Nowotwór nie zajmuje narządów wewnętrznych. Metodą leczenia z wyboru jest wycięcie chirurgiczne zmiany [39].

\section{PIERWOTNIE SKÓRNE CHŁONIAKI Z KOMÓREK B} (TAB. 12)

O diagnozie decyduje zarówno wynik badania histopatologicznego, jak i obraz kliniczny (konieczne różnicowanie z chłoniakami systemowymi o analogicznym lub podobnym obrazie $\mathrm{w}$ badaniu histopatologicznym). 
Table 12. Treatment of primary cutaneous B-cell lymphomas

Tabela 12. Leczenie chłoniaków pierwotnie skórnych B-komórkowych

\begin{tabular}{|c|c|}
\hline $\begin{array}{l}\text { Primary cutaneous follicle centre } \\
\text { lymphoma/Pierwotny skórny chłoniak } \\
\text { z ośrodków rozmnażania }\end{array}$ & $\begin{array}{l}\text { - radiotherapy or surgical excision of solitary lesions/ radioterapia lub chirurgiczne usunięcie } \\
\text { pojedynczych zmian } \\
\text { - for multiple lesions, corticosteroids topically or in injections directly into skin lesions, IFN- } \alpha \\
\text { or rituximab intralesionally/gdy zmian jest więcej - kortykosteroidy miejscowo } \\
\text { lub w iniekcjach bezpośrednio do zmian skórnych, IFN- } \alpha \text { lub rytuksymab doogniskowo } \\
\text { - chemotherapy: chlorambucil or R-COP or R-CHOP in cases with diffuse cutaneous lesions } \\
\text { or internal organ involvement/chemioterapia: chlorambucyl lub R-COP, lub R-CHOP } \\
\text { w przypadku rozsianych zmian skórnych lub zajęcia narządów wewnętrznych }\end{array}$ \\
\hline $\begin{array}{l}\text { Primary cutaneous marginal zone } \\
\text { lymphoma/Pierwotny skórny chłoniak } \\
\text { strefy brzeżnej }\end{array}$ & $\begin{array}{l}\text { - antibiotic therapy (penicillin V or doxycycline) in cases with diagnosed Borrelia burgdorferi } \\
\text { infection/antybiotykoterapia (v-penicylina lub doksycyklina) w przypadku z potwierdzonym } \\
\text { zakażeniem Borrelia burgdorferi } \\
\text { - therapies as in primary cutaneous follicle centre lymphoma/metody jak w pierwotnym } \\
\text { skórnym chłoniaku z ośrodków rozmnażania } \\
\text { - TG I042 (adenovirus-IFN- } \gamma \text { ) intralesionally/TG I042 (adenowirus-IFN- } \gamma \text { ) doogniskowo }\end{array}$ \\
\hline $\begin{array}{l}\text { Primary cutaneous diffuse large B-cell } \\
\text { lymphoma, leg type/Pierwotny skórny } \\
\text { chłoniak rozlany z dużych komórek B } \\
\text { typu kończynowego }\end{array}$ & $\begin{array}{l}\text { - } \mathrm{R}-\mathrm{CHOP} \text { with localized radiotherapy/R-CHOP z radioterapią miejscową } \\
\text { - radiotherapy in chemotherapy - ineligible patients/radioterapia u osób niekwalifikujących się } \\
\text { do chemioterapii }\end{array}$ \\
\hline
\end{tabular}

R-COP - rituximab + cyclophosphamide + Oncovin (vincristine) + prednisone, $R$-CHOP - rituximab + cyclophosphamide + hydroxydaunomycin (doxorubicin) + Oncovin (vincristine) + prednisone, IFN- $\gamma$ - interferon- $/$ R-COP - rytuksymab + cyklofosfamid + Oncovin (winkrystyna) + prednizon, R-CHOP - rytuksymab + cyklofosfamid + hydroksydaunomycyna (doksorubicyna) + Oncovin (winkrystyna) + prednizon, IFN- $\gamma$ - interferon $\gamma$.

\section{Primary cutaneous follicle centre lymphoma}

Primary cutaneous follicle centre lymphoma (PCFCL) occurs mainly in adults, and the median age at diagnosis is 51 years. The PCFCL presents with elevated flat papules or nodular infiltrates having an erythematous base, either occurring alone or in clusters. The lesions are located primarily on the head and trunk, less commonly on the lower extremities. The formation of tumours may be preceded by erythematous papules and infiltrates by several months or years. Histopathological examination of the skin demonstrates nodular, diffuse or mixed infiltrates within the dermis, sparing the epidermis and containing centrocytes admixed with centroblasts. Lymphoma cells exhibit the phenotypes CD20+, CD79a+, bcl-6+, CD10+, CD5-, CD43. PCFCL with solitary lesions can be treated with radiotherapy or surgical excision, and multiple lesions - with corticosteroids administered topically or in the form of injections directly into cutaneous lesions, IFN- $\alpha$ or rituximab intralesionally. Chemotherapy is used on an exceptional basis, chiefly in cases with diffuse cutaneous lesions or internal organ involvement. In such patients, chlorambucil or polychemotherapy consisting of rituximab combined with COP (cyclophosphamide, vincristine, prednisone) or $\mathrm{CHOP}$ is recommended. The prognosis is very good regardless of the type of cancerous infiltration (nodular or diffuse), centroblast count and the presence of grouped or multifocal infiltrates. The 5-year survival rate is $95 \%[5-8,40]$.

\section{Pierwotny skórny chłoniak z ośrodków rozmnażania}

Pierwotny skórny chłoniak z ośrodków rozmnażania dotyczy głównie osób dorosłych (mediana wieku przy rozpoznaniu 51 lat). Chłoniak ten objawia się występowaniem pojedynczych lub skupionych, płaskowyniosłych grudek lub guzowatych nacieków na podłożu rumieniowym. Zmiany są zlokalizowane głównie na głowie i tułowiu, rzadziej na kończynach dolnych. Pojawienie się rumieniowych grudek i nacieków może o kilka miesięcy lub lat wyprzedzać rozwój guzów. W badaniu histopatologicznym skóry widoczne są guzkowe, rozlane lub mieszane nacieki w skórze właściwej oszczędzające naskórek i składające się z centrocytów z domieszką centroblastów. Komórki chłoniaka wykazują fenotyp CD20+, CD79a+, bcl-6+, CD10+, CD5-, CD43. W leczeniu można zastosować radioterapię lub chirurgiczne usunięcie pojedynczych zmian, a gdy zmian jest więcej - kortykosteroidy miejscowo lub w iniekcjach bezpośrednio do zmian skórnych, IFN- $\alpha$ lub rytuksymab doogniskowo. Chemioterapię stosuje się wyjątkowo, głównie w przypadku rozsianych zmian skórnych lub zajęcia narządów wewnętrznych. Zaleca się wówczas leczenie chlorambucylem lub polichemioterapię wg schematu: rytuksymab w połączeniu z COP (cyklofosfamid, winkrystyna, prednizon) lub z CHOP. Rokowanie jest bardzo dobre bez względu na typ nacieku nowotworowego (guzkowy czy rozlany), liczbę centroblastów, obecność nacieków zgrupowanych lub wieloogniskowych. Pięć lat przeżywa 95\% chorych [5-8, 40]. 


\section{Primary cutaneous marginal zone lymphoma}

Primary cutaneous marginal zone lymphoma (PCMZL) is characterized by livid-red papules, infiltrates or nodules, which rarely ulcerate. The lesions may be recurrent in nature. Lymph node or internal organ involvement is uncommon. The cutaneous lesions may sometimes resolve spontaneously. Attention is drawn to a probable link between the disease and Borrelia burgdorferi infection. Histopathological evaluation of the skin shows nodular or diffuse infiltrates, sparing the epidermis, composed of small lymphocytes, cells from the marginal zone of reactive lymphatic follicles, as well as lymphoplasmacytic and plasmatic cells with some centroblasts, immunoblasts, histiocytes and eosinophils. Marginal zone $B$ cells have a distinct phenotype: CD20+, CD79a+, BCL2+, but CD5-, CD10-, BCL6-. Patients diagnosed with $B$. burgdorferi infection should begin treatment with antibiotic therapy (V-penicillin or doxycycline). Other therapeutic modalities are the same as in primary cutaneous follicle centre lymphoma. Promising outcomes have been reported in a clinical trial with TG1042 (adenovirus-IFN- $\gamma$ ) administered intralesionally. The prognosis is very good. Complete remission can be achieved in 50\% of patients, and the 5-year survival rate is close to $100 \%[5-8,40]$.

\section{Primary cutaneous diffuse large B-cell lymphoma, leg type}

Primary cutaneous large B-cell lymphoma (LBCL), leg type, affects primarily elderly women, at the age of about 70 years. The clinical presentation of LBCL includes red or violaceous-red tumours affecting one or both legs. Extracutaneous lesions are also frequently observed. Histopathological evaluation reveals a monomorphic diffuse infiltrate within the dermis, with no epidermal involvement. Lymphoma lymphocytes express the antigens CD20+, CD79a+, BCL2+, CD10-, BCL6+/-, and IRF4/MUM1+ and FOX-P1+. The recommended therapeutic modality in patients with lesions limited to the skin is rituximab combined with CHOP and local radiotherapy - or with radiotherapy alone in patients who are not eligible for CHOP. Multiple cutaneous lesions at diagnosis exacerbate the prognosis. In cases with a solitary tumour the 5-year survival rate is 100\%, and it drops to $45 \%$ and $36 \%$ in patients with multiple tumours located on one and both extremities, respectively $[5-8,40]$.

\section{SUMMARY}

It needs to be noted that therapeutic decisions in all cases are made by the physician who takes into account contemporary medical knowledge, and the potential efficacy and safety profile of different therapies, which

\section{Pierwotny skórny chłoniak strefy brzeżnej}

W tym typie chłoniaka na skórze tułowia i ramion obserwuje się czerwonosine grudki, nacieki lub guzy, rzadko wrzodziejące. Zmiany mogą mieć charakter nawrotowy. Zajęcie węzłów chłonnych czy narządów wewnętrznych stwierdza się rzadko. Czasami dochodzi do samoistnej remisji zmian skórnych. Podkreśla się prawdopodobny związek choroby z zakażeniem Borrelia burgdorferi. W badaniu histopatologicznym skóry obecne są guzkowe lub rozlane nacieki oszczędzające naskórek, składające się z małych limfocytów, komórek strefy brzeżnej reaktywnych grudek chłonnych, a także komórek limfoplazmocytowych i plazmatycznych z domieszką centroblastów, immunoblastów, histiocytów i eozynofilów. Komórki B strefy brzeżnej mają charakterystyczny fenotyp: CD20+, CD79a+, BCL2+, ale CD5-, CD10-, BCL6-. U chorych z potwierdzonym zakażeniem $B$. burgdorferi należy rozpocząć leczenie od antybiotykoterapii (penicylina V lub doksycyklina). Pozostałe metody są takie jak w chłoniaku z ośrodków rozmnażania. Opublikowano obiecujące wyniki badania klinicznego z lekiem TG1042 (Adenovirus-IFN- $\gamma$ ) podawanym doogniskowo. Rokowanie jest bardzo dobre. Całkowita remisja jest możliwa u 50\% chorych, a 5-letnie przeżycie osiąga się prawie w 100\% przypadków [5-8, 40].

\section{Pierwotny skórny chłoniak rozlany z dużych komórek B typu kończynowego}

Ten typ chłoniaka występuje głównie u kobiet ok. 70. roku życia. Charakterystyczne są czerwone lub fioletowosine guzy na jednej lub obu kończynach dolnych. Często obserwuje się również zmiany pozaskórne. W badaniu histopatologicznym stwierdza się monomorficzny, rozlany naciek w skórze, bez zajęcia naskórka. Limfocyty chłoniaka wykazują ekspresję antygenów CD20+, CD79a+, BCL2+, CD10-, BCL6+/-, a także IRF4/MUM1+ i FOX-P1+. W postaciach ograniczonych do skóry zaleca się stosowanie polichemioterapii według schematu: rytuksymab w połączeniu z CHOP oraz $\mathrm{z}$ radioterapią miejscową lub tylko radioterapią u osób niekwalifikujących się do CHOP. Liczne zmiany skórne w dniu diagnozy pogarszają rokowanie. Gdy guz jest jeden, 5-letnie przeżycie osiąga $100 \%$ chorych, kiedy guzy są liczne na jednej kończynie - $45 \%$, a gdy na obu kończynach - $36 \%$ $[5-8,40]$.

\section{PODSUMOWANIE}

Należy podkreślić, że w każdym przypadku decyzje terapeutyczne podejmuje lekarz, kierując się współczesną wiedzą medyczną oraz potencjalną skutecznością i profilem bezpieczeństwa, które mogą być 
may vary across patients. Even though the treatment modalities presented above are based on the current state of medical knowledge and EBM, they should be regarded as recommendations of a general nature. różne u różnych pacjentów. Przedstawione w tym artykule metody leczenia stanowią jedynie rekomendacje o charakterze ogólnym, choć oparte są na aktualnej wiedzy medycznej, z uwzględnieniem EBM.

\section{CONFLICT OF INTEREST}

The authors declare no conflict of interest.

\section{KONFLIKT INTERESÓW}

Autorzy deklarują brak konfliktu interesów.

\section{References}

\section{Piśmiennictwo}

1. Whitmore A.S., Holly E.A., Lee I.M., Abel EA, Adams RM, Nickoloff BJ, et al.: Mycosis fungoides in relation to environmental exposure and immune response. J Natl Cancer Inst 1989, 81, 1560-1567.

2. Li G., Vowels B.R., Benoit B.M., Rook A.H., Lessin S.R.: Failure to detect human T-lymphotropic virus type I (HTLV-I) proviral DNA in cell lines and tissues from patients with cutaneous T-cell lymphoma. J Invest Dermatol 1996, 7, 308-313.

3. Agar N.S., Wedgeworth E., Crichton S., Mitchell T.J., Cox M., Ferreira S., et al.: Survival outcomes and prognostic factors in mycosis fungoides/Sézary syndrome: validation of the revised International Society for Cutaneous Lymphomas/European Organisation for Research and Treatment of Cancer staging proposal. J Clin Oncol 2010, 28, 4730-4739.

4. Jahan-Tigh R.R., Huen A.O., Lee G.L., Pozadzides J.V., Liu P., Duvic M.: Hydrochlorothiazide and cutaneous T-cell lymphoma: prospective analysis and case series. Cancer 2013, 119, 825-831.

5. Sokołowska-Wojdyło M.: Pierwotne chłoniaki skóry. [In:] Onkologia kliniczna. M. Krzakowski, P. Potemski, K. Warzocha, P. Wysocki (eds.). Via Medica, Gdańsk, 2015, 1382-1402.

6. Sokołowska-Wojdyło M.: Pierwotne chłoniaki skóry. [In:] Zalecenia postępowania diagnostyczno-terapeutycznego w nowotworach złośliwych. Vol. 2. Nowotwory układu chłonnego. K. Warzocha, M. Prochorec-Sobieszek, E. Lech-Marańda (eds.). VM Media, Gdańsk, 2013, 948-968.

7. Sokołowska-Wojdyło M.: Zasady postępowania w chłoniakach pierwotnie skórnych. [In:] Praktyka hematologiczna. W.W. Jędrzejczak, T. Robak, M. Podolak-Dawidziak (eds.). Termedia, Poznań, 2015, 271-284.

8. Sokołowska-Wojdyło M., Lech-Marańda E., Placek W., Meder J., Zaucha J.M., Walewski J.: Leczenie pierwotnych chłoniaków skóry. Rekomendacje Sekcji Chłoniaków Skóry Polskiej Grupy Badawczej Chłoniaków (PLRG). Onkol Prakt Klin 2010; 6: 29-47.

9. Wong H.K., Mishra A., Hake T., Porcu P.: Evolving insights in the pathogenesis and therapy of cutaneous T-cell lymphoma (mycosis fungoides and Sezary syndrome). Br J Haematol 2011, 155, 150-166.

10. Sokołowska-Wojdyło M., Olek-Hrab K., Ruckemann-Dziurdzińska K.: Primary cutaneous lymphomas: diagnosis and treatment. Postep Dermatol Alergol 2015, 32, 368-383.

11. Bagot M.: Cutaneous T-cell lymphoma (CTCL) - classification, staging, and treatment options. Dermatol Clin 2008, 26 (Suppl 1), 3-12.

12. Swerdlow S., Campo E., Harris N., Jaffe E.S., Pileri S.A., Stein H., et al. (ed.).: WHO Classification of Tumours of Haematopoietic and Lymphoid Tissues. IARC Press, Lyon 2008.

13. Reich A., Maj J., Schlue J., Kreipe H.H., Mazur G.: Primary cutaneous peripheral T-cell non-Hodgkin lymphoma, not otherwise specified, with cytotoxic features. Int J Dermatol 2010, 49, 967-969.

14. Stevens S.R., Ke M.S., Parry E.J., Mark J., Cooper K.D.: Quantifying skin disease burden in mycosis fungoides- type cutaneous T-cell lymphomas: the severity-weighted assessment tool (SWAT). Arch Dermatol 2002, 138, 42-48.

15. Wilcox R.A.: Cutaneous T-cell lymphoma: 2014 update on diagnosis, risk-stratification, andmanagement. Am J Hematol 2014, $89,837-851$

16. Kempf W., Sander C.A.: Classification of cutaneous lymphomas - an update. Histopathology 2010, 56, 57-70.

17. Maj J., Kołodziej T., Woźniak Z.: Subcutaneous T-cell lymphoma. A clinical and histopathological study of an additional case. Acta Dermatovenerol Croat 2004, 12, 274-277.

18. Willemze R., Jansen P.M., Cerroni L., Berti E., Santucci M., Assaf C., et al.: Subcutaneous panniculitis like T-cell lymphoma: definition, classification and prognostic factors: an EORTC Cutaneous Lymphoma Group Study of 83 cases. Blood 2008, 111, 838-845.

19. Maryniak R.K., Jankowska-Konsur A.: Histoclinical and immunohistochemical diagnosis of cutaneous lymphomas. Pol J Pathol 2011, 62 (4 Suppl 3), 1-23.

20. Pimpinelli N., Olsen E.A., Santucci M., Vonderheid E., Haeffner A.C., Stevens S., et al.: International Society for Cutaneous Lymphoma. Defining early mycosis fungoides. J Am Acad Dermatol 2005, 53, 1053-1063.

21. van Doorn R., Scheffer E., Willemze R.: Follicular mycosis fungoides: a distinct disease entity with or without associated follicular mucinosis. Arch Dermatol 2002, 138, 191-198.

22. Gerami P., Rosen S., Kuzel T., Boone S.L., Guitart J.: Folliculotropic mycosis fungoides: an aggressive variant of cutaneous T-cell lymphoma. Arch Dermatol 2008, 144, 738-746.

23. Trautinger F., Eder J., Assaf C., Bagot M., Cozzio A., Dummer R., et al.: European Organisation for Research and Treatment of Cancer consensus recommendations for the treatment of mycosis fungoides/Sézary syndrome - Update 2017. Eur J Cancer $2017,77,57-74$

24. Plettenberg H., Stege H., Megahed M., Ruzicka T., Hosokawa Y., Tsuji T., et al.: Ultraviolet A1 (340-400 nm) phototherapy for cutaneous T-cell lymphoma. J Am Acad Dermatol 1999, 41, 47-50.

25. Zane C., Leali C., Airo P., De Panfilis G., Pinton P.C.: “High-dose" UVA1 therapy of widespread plaquetype, nodular, and erythrodermic mycosis fungoides. J Am Acad Dermatol 2001, 44, 629-633. 
26. Musson R.E., Hensbergen P.J., Westphal A.H., Temmink W.P., Deelder A.M., van Pelt J., et al.: UVA1 radiation inhibits calcineurin through oxidative damage mediated by photosensitization. Free Radic Biol Med 2011, 50, 1392-1399.

27. Kamstrup M.R., Lindahl L.M., Gniadecki R., Iversen L., Skov L., Petersen P.M., et al.: Low-dose total skin electron beam therapy as a debulking agent for cutaneous T-cell lymphoma: an open-label prospective phase II study. Br J Dermatol 2012, $166,399-404$.

28. Navi D., Riaz N., Levin Y.S., Sullivan N.C., Kim Y.H., Hoppe R.T.: The Stanford University experience with conventionaldose, total skin electron-beam therapy in the treatment of generalized patchor plaque (T2) and tumor (T3) mycosis fungoides. Arch Dermatol 2011, 147, 561-567.

29. Chan D.V., Aneja S., Honda K., Carlson S., Yao M., Katcher J., et al.: Radiation therapy in the management of unilesional primary cutaneous T-cell lymphomas. Br J Dermatol 2012, 166, 1134-1137.

30. Mann B.S., Johnson J.R., He K., Sridhara R., Abraham S., Booth B.P., et al.: Vorinostat for treatment of cutaneous manifestations of advanced primary cutaneous T-cell lymphoma. Clin Cancer Res 2007, 13, 2318-2322.

31. Quereux G., Marques S., Nguyen J.M., Bedane C., D’incan M., Dereure O., et al.: Prospective multicenter study of pegylated liposomal doxorubicin treatment in patients with advanced or refractory mycosis fungoides or Sézary syndrome. Arch Dermatol 2008, 144, 727-733.

32. Duarte R.F., Schmitz N., Servitje O., Sureda A.: Haematopoietic stem cell transplantation for patients with primary cutaneous T-cell lymphoma. Bone Marrow Transplant 2008, 41, 597-604.

33. Shiratori S., Fujimoto K., Nishimura M., Hatanaka K.C., Kosugi-Kanaya M., Okada K., et al.: Allogeneic hematopoietic stem cell transplantation following reduced-intensity conditioning for mycosis fungoides and Sezary syndrome. Hematol Oncol 2016, 34, 9-16.

34. Zinzani P.L., Baliva G., Magagnoli M., Bendandi M., Modugno G., Gherlinzoni F., et al.: Gemcitabine treatment in pretreated cutaneous T-cell lymphoma: experience in 44 patients. J Clin Oncol 2000, 18, 2603-2606.

35. Prince H.M., Whittaker S., Hoppe R.T.: How I treat mycosis fungoides and Sézary syndrome. Blood 2009, 114, 4337-4353.

36. Kempf W., Pfaltz K., Vermeer M.H., Cozzio A., Ortiz-Romero P.L., Bagot M., et al.: EORTC, ISCL, and USCLC consensus recommendations for the treatment of primary cutaneous CD30-positive lymphoproliferative disorders: lymphomatoid papulosis and primary cutaneous anaplastic large-cell lymphoma. Blood 2011, 118, 4024-4035.

37. Maj J., Jankowska-Konsur A.: CD30+ T-cell Lymphoproliferative disorders of the skin. [In:] New research on cutaneous lymphomas. Nova Science Publishers, New York 2007, 87-103.

38. Younes A., Bartlett N.L., Leonard J.P., Kennedy D.A., Lynch C.M., Sievers E.L., et al.: Brentuximab vedotin (SGN-35) for relapsed CD30-positive lymphomas. N Engl J Med 2010, 363, 1812-1821.

39. Murga C.Z., Smith L.B.: Primary cutaneous acral CD8+ T cell lymphoma Copyright: 2002-2017, PathologyOutlines.com, Inc. Revised: 28 March 2017, last major update August 2016.

40. Senff N.J., Noordijk E.M., Kim Y.H., Bagot M., Berti E., Cerroni L., et al.: European Organization for Research and Treatment of Cancer and International Society for Cutaneous Lymphoma consensus recommendations for the management of cutaneous B-cell lymphomas. Blood 2008, 112, 1600-1609.

Received: 14.05 .2017

Accepted: 13.06.2017

Otrzymano: $14.05 .2017 \mathrm{r}$

Zaakceptowano: 13.06.2017 r.

How to cite this article

Sokołowska-Wojdyło M., MajJ., Robak E., PlacekW., Wojas-Pelc A., Jankowska-Konsur A., Olek-Hrab K., Gniadecki R., Rudnicka L.: Primary cutaneous lymphomas - diagnostic and therapeutic guidelines of the Polish Dermatological Society. Dermatol Rev/ Przegl Dermatol 2017, 104, 243-268. DOI: https://doi.org/10.5114/dr.2017.68774. 